\title{
Measuring the efficiency of the healthcare sector in Poland - a window-DEA evaluation
}

\author{
Katarzyna Miszczynska \\ Public Finance, Faculty of Economics and Sociology, University of Lodz, \\ Lodz, Poland, and \\ Piotr Marek Miszczyński \\ Operations Research, Faculty of Economics and Sociology, University of Lodz, \\ Lodz, Poland
}

The efficiency of the healthcare sector in Poland

Received 9 June 2020 Revised 24 November 2020 2 March 2021

Accepted 5 March 2021

\begin{abstract}
Purpose - The main aim of the study was to measure and assess the efficiency of the healthcare system in Poland. Design/methodology/approach - An output-oriented Data Envelopment Analysis model with a 2-years window analysis extension was used between 2013 and 2018. The analysis was completed with a determination of the sources of productivity changes (between the first and last year of the study period) and factors that influence efficiency.

Findings - Efficient regions have been identified and the spatial diversity in their efficiency was confirmed. The study identified individual efficiency trends together with "all-windows" best and worst performers. Using panel modeling, it was confirmed that the efficiency of health protection is influenced by, among others, accreditation certificates, the length of the waiting list or the number of medical personnel.

Research limitations/implications - Although the analysis was conducted at the voivodeship level (NUTS2), which was fully justified, it would be equally important to analyze data with a lower aggregation level. It would be extremely valuable from the perspective of difficulties faced by the healthcare system in Poland.

Practical implications - The identification of areas and problems affecting the efficiency of the healthcare system in Poland may also be a hint for other countries with similar system solutions that also struggle with the same problems.

Originality/value - The paper explains the efficiency of the country's healthcare system while also paying attention to changes in its level, factors influencing it, spatial diversity and impact on the sector functioning.

Keywords Efficiency measurement, Health economics, Data envelopment analysis, Window analysis

Paper type Research paper
\end{abstract}

\section{Introduction}

One of the most critical public policy issues in recent decades is healthcare. Currently, especially during the COVID-19 pandemic, it has gained a particularly strong resonance and justification (Tarantola et al., 2020). Therefore, the efficiency of using public resources, which has been pointed out in many studies (Boe and Kvalvik, 2015; Daniels, 2016; Stefko et al., 2018), became particularly important. It is a subject of research from two main perspectives: the whole system (Kujawska, 2018; Lobo and Araujo, 2017; Rój, 2011; Stefko et al., 2018) and individual organizations, for example hospitals (Biørn et al., 2003; Ghafari et al., 2019; JehuAppiah et al., 2014; Jewczak and Żółtaszek, 2011; Lachowska, 2017; Miszczyńska, 2019), both

(C) Katarzyna Miszczynska and Piotr Marek Miszczyński. Published by Emerald Publishing Limited. This article is published under the Creative Commons Attribution (CC BY 4.0) licence. Anyone may reproduce, distribute, translate and create derivative works of this article (for both commercial and noncommercial purposes), subject to full attribution to the original publication and authors. The full terms of this licence may be seen at http://creativecommons.org/licences/by/4.0/legalcode

This article is an output from the research project "Multicriteria assessment of efficiency of public hospitals in Poland and identification of determinants of their indebtedness" financed by the National Science Centre, decision number DEC-2016/23/N/HS4/03410.

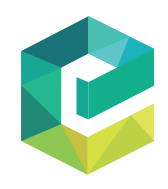

International Journal of Productivity and Performance Management Vol. 71 No. 7,2022 pp. $2743-2770$ 
IJPPM 71,7

2744

in Poland and internationally. A detailed literature review on efficiency analysis in healthcare was presented by Worthington (2004) and Zakowska and Godycki-Cwirko (2020).

Although the Polish healthcare sector has undergone numerous restructuring processes in recent decades, which resulted in greater competition, changes in the organizational form of healthcare entities and the application of new technologies, there is still a need and space for reforms aimed at improving its efficiency. One of the main problems indicated in the reports of the Supreme Audit Office is the excessive concentration of human resources, equipment or the number of services provided in selected regions of Poland (Suppreme Chamber of Control, 2019). Thus, there are regions that lack not only medical resources, but also the funds to obtain them. Paradoxically, the latest report on the functioning of the National Health Fund (which is the main payer and organizer of the healthcare system in Poland) showed that patients' access to health services is also a frequent problem when the therapeutic potential of medical entities is not fully used (Suppreme Chamber of Control, 2019). All this leads the authors of the study to the conclusion that there is some variation in the efficiency of the healthcare sector in Poland. Taking the above into account, the main aim of the study was to assess the efficiency of the healthcare system in Poland from a regional perspective for the years 2013 and 2018. To this end, the paper addresses the following research questions:

(1) Did the efficiency of the healthcare sector within regions improve between 2013 and 2018 ?

(2) What are the sources of inefficiencies and the possibilities to limit them?

(3) What are the factors that influence efficiency of healthcare?

The study was divided into two parts. In the first part, the analysis was performed using Data Envelopment Analysis (DEA), a non-parametric efficiency analysis method that is one of the most popular methods for determining the efficiency of social and economic entities. The study was extended by an analyzing of the sources of productivity changes between the first and last year of the studied period. At the end the window analysis was incorporated. It not only helped to evaluate healthcare technical efficiency in individual regions and quantify the underlying regional disparities, but it also enabled year-by-year comparisons of the results (Gannon, 2011; McKillop et al., 1999; Pulina et al., 2010). In the second part of the study, using panel econometric modeling, factors influencing the efficiency estimated in the first part of the study were determined.

A study of such a comprehensive approach, covering temporal and spatial aspects in terms of efficiency assessment, has never been carried out in the Polish healthcare sector before. The study makes it possible to identify factors influencing the efficiency, assess sector's efficiency and highlight regional differences while also indicating the possibilities of limiting them. The identification of areas and problems that affect the efficiency of the healthcare system in Poland may also be a hint for other countries with similar systems that also struggle with the same problems. The results of the study may also be valuable in shaping the health policy of the state and introducing changes in the healthcare sector in countries with a universal health insurance model. In the group of countries potentially interested in the results of the research are: the Czech Republic, Hungary and Slovakia. The comparative research of the functioning of healthcare systems in these countries was carried out by, among others, Mihalyi who developed an analytical framework to compare the healthcare systems of the former centrally planned economies (Mihalyi, 2014). The Polish healthcare system was also compared with the systems of the Czech Republic, Hungary and Slovakia in a study conducted by Dlouhy. The author aimed at evaluating the performance of the healthcare systems in Visegrad countries (Dlouhý, 2016). All in all, conducting this type of research seems fully justified. Internationally, the issue of measuring the differences in performance between regions, also within one 
country, was conducted by, inter alia, Fanelli et al. (2020), Fanelli and Zangrandi (2017), Aumann et al. (2015) and Meisinger et al. (2006). Moreover, in the literature on the subject, there are examples of studies comparing healthcare systems in different countries. Jaworzyńska (2016) compared the healthcare system in Poland and in Netherlands, USA, Germany and Great Britain. Wendt (2009) made a comparative analysis of financing, service provision and access to healthcare in European countries. Backfield et al. compared different healthcare systems from the perspective of classification, convergence, institutions, inequalities. They also indicated that the countries whose health systems should be compared are Poland, Bulgaria, Czech Republic, Hungary and Russia (Backfield et al., 2013). To sum up, the conducted study will allow to assess the efficiency of healthcare system in Poland and to identify the sector's efficiency determinants. These results, as already mentioned, will be important for countries with the same or similar healthcare system design and will make a clear contribution to the development of the literature on the subject.

The text is structured as follows. First, we present an overview of the healthcare sector in Poland to better understand how it function. Secondly, we present the study design, the method, characterize the data and the sample and justify the selection of variables in the literature. Finally, we present the findings and discuss their conceptual, practical and policy implications.

\section{The healthcare sector in Poland}

The healthcare sector in Poland is an element of the public finance system and is based on a universal health insurance model. According to the Constitution every citizen has the right to health protection, irrespective of their financial situation. Thus, everyone has equal access to healthcare services financed from public funds and, provided by the public authorities.

From an institutional perspective, the Polish healthcare system is shaped by four basic groups of entities: the organizer of the system (government, parliament, local government units), the payer (National Health Fund), the service providers (entities providing health services) and the beneficiaries (Miszczyńska, 2019). The system also includes entities such as the Main Pharmaceutical Inspectorate, the State Sanitary Inspection and representatives of patients' interests.

The contributions from public health insurance and budget state/special purpose funds are the two main sources of funding. Roughly $70 \%$ of healthcare services in Poland are financed from public funds (Figure 1). This share has remained virtually unchanged over the past years. However, almost $80 \%$ of this value is covered by the National Health Fund. The funds from public health insurance are administered by the National Health Fund. As of January 1,2007 , it amounts to $9 \%$, with $7.75 \%$ deducted from income tax and $1.25 \%$ covered

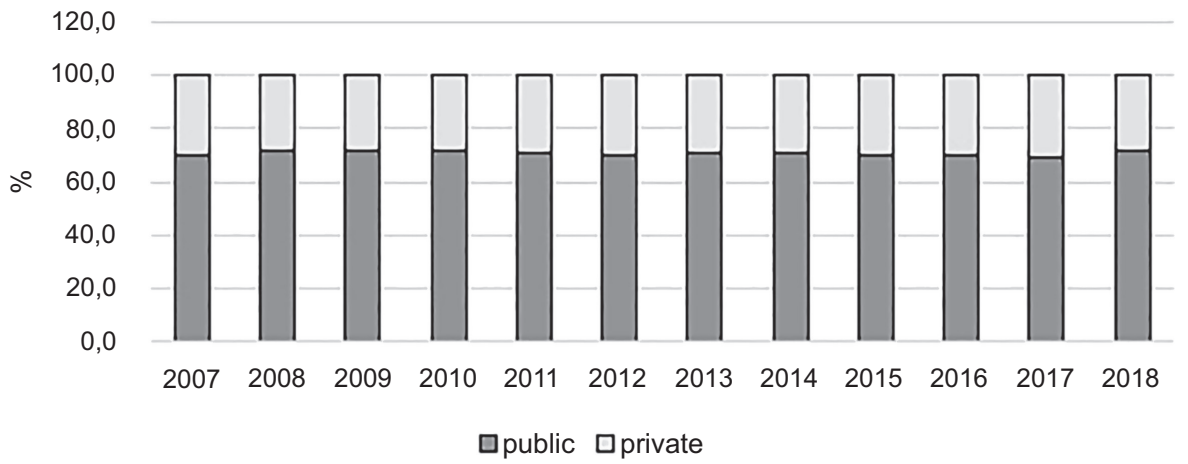

Source(s): Own elaboration
The efficiency of the healthcare sector in Poland 
IJPPM

71,7

2746

by the insured person. Each citizen pays an insurance premium depending on income, and it is paid via the Social Insurance Institution or the Agricultural Social Insurance Fund (in the case of farmers) to the National Health Fund. The insurance protection covers employees, the self-employed, students, the retired and the unemployed. Insurance premiums paid in the form of taxes by the state budget or special funds refer to a narrow group of citizens, including students, farmers and their household members (Magda and Szczygielski, 2011). Labor offices pay contributions for the unemployed, and social welfare funds pay for non-working people who are not registered with labor offices and who meet the income criterion (Miszczyńska and Miszczyński, 2020). In addition, employers bear the costs of financing occupational medicine. Health insurance formally guarantees access to a wide range of healthcare services without the need for co-payments. Therefore, patients do not incur costs related to treatment during their stay in hospital. It is fully covered by the insurance. There are exceptions, however, as patients must pay for selected drugs, dentistry, some laboratory tests and rehabilitation equipment and treatment.

Apart from the National Health Fund and the state budget, local government units (LGUs) also organize the healthcare system and finance certain health protection activities (Szetela, 2015). These obligations result directly from the administrative division of the country into: communes, poviats and voivodeships (see Figure 2). The division into voivodeships corresponds Europeans Union's NUTS 2 classification, and this is also how we performed our analysis. The role of voivodeships in public health is considered in the following areas: environmental protection, protection against infectious diseases, social limitations of disability phenomena and protection against threats related to adverse social conditions, i.e. unemployment or, social pathologies (Miszczyńska and Antczak, 2020). The structure of public expenditure taking into account the above-mentioned entities is presented in Figure 3. In 2018, local governments in Poland allocated PLN 3.8 billion for tasks related to health protection (GUS, 2019). Undoubtedly, the most essential and fundamental task of voivodeships is to organize the healthcare system.

According to a study by the Main Statistical Office (GUS, 2019), in 2018, more than 7.6 million patients (Figure 4) were cured in 181,000 hospital beds in 926 general public hospitals. The hospital base by voivodeships is characterized by concentration (Figure 5), with some voivodeships in Poland having a high concentration of specialist hospitals. These voivodeships almost become centers that provide, for example, highly specialized services in cardiology.

Figure 2.

Administrative division of Poland

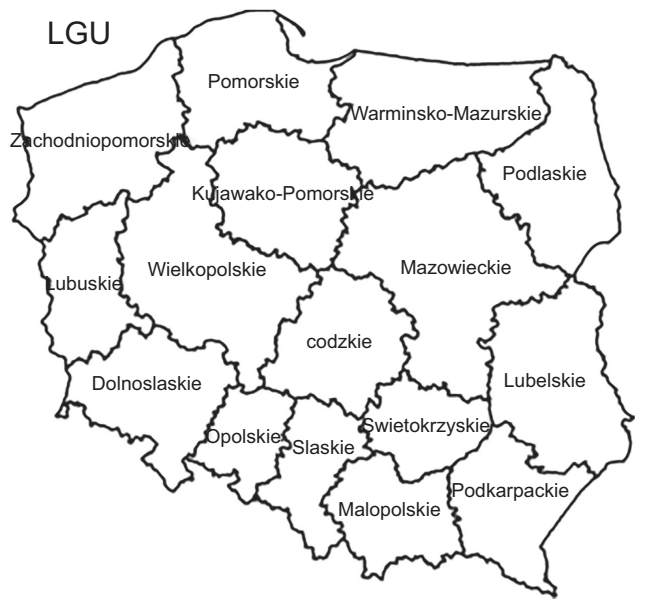

Source(s): Own elaboration 


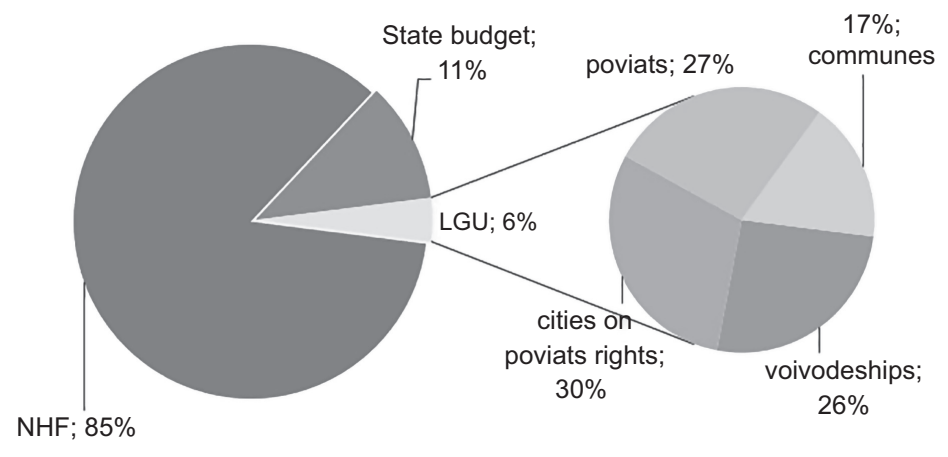

Source(s): Own elaboration

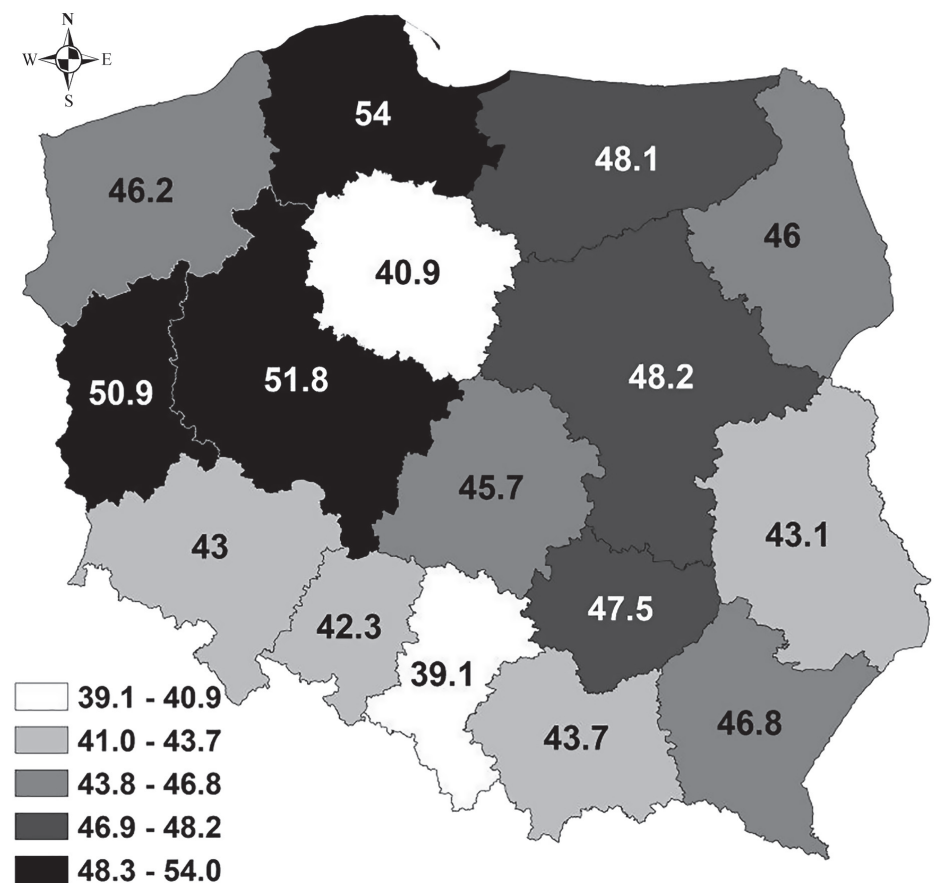

Source(s): Own elaboration
The efficiency of the healthcare sector in Poland

2747

Figure 3. The structure of public expenditure sources on healthcare services
Figure 4.

Rate of patients treated per year per one hospital bed

Public hospitals are the basic units that provide round-the-clock health services in Poland, and they may be established by: medical universities, local government units and ministries (for more detail see Miszczyńska and Antczak, 2020; Szetela, 2017). They absorb most of the funds allocated to healthcare as they are obliged to provide each patient not only with health services, but also pharmaceuticals (including medical materials), rooms and with food (Miszczyńska and Antczak, 2020). It is the Constitution that obliges them to provide necessary assistance to every citizen in a life-threatening situation, regardless of their 


\section{IJPPM \\ 71,7}

\section{8}

Figure 5.

Number of hospitals per voivodships

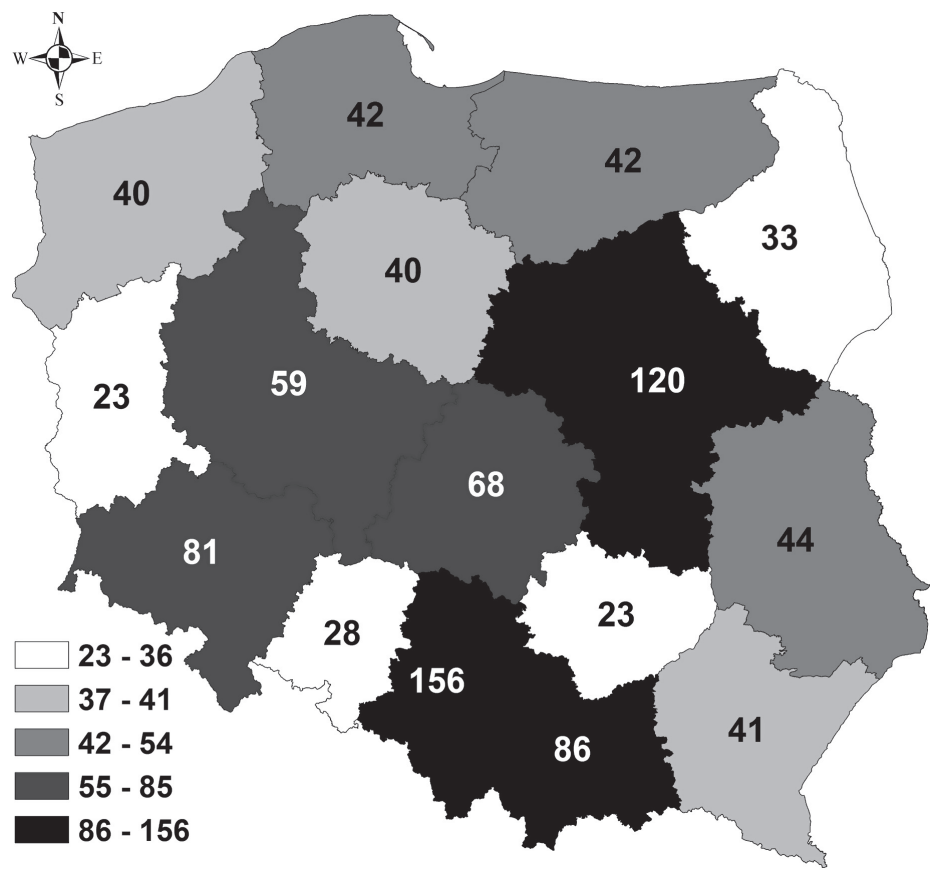

Source(s): Own elaboration

financial condition. Hospital funding is provided by: the National Health Fund, public administration bodies (i.e. the Ministry of Health finances highly specialized procedures), local government units (concerning financing health programs) and the European Union.

Medical personnel is an inseparable element of the healthcare sector. According to a Ministry of Health study (GUS, 2019), no significant annual fluctuations in their number were observed between 2011 and 2018. When comparing licensed and working personnel between 2011 and 2018, public healthcare facilities employed an average of $61 \%$ of people licensed to practice medicine. In the case of nurses, it was $67 \%$, midwives $-65 \%$, and dentists $-34 \%$. According to the Main Statistical Office's report (GUS, 2019), in 2018, 87,749 doctors, 12,900 dentists, 182,671 nurses and 22,372 midwives worked in public healthcare entities. Figure 6 and Figure 7 present the distribution of medical personnel in each voivodeships in 2017.

\section{Data and methodology \\ Study design}

The study was conducted in several stages. Firstly, an in-depth literature review was carried out in terms of factors that influence the efficiency of the healthcare sector. Then, we analyzed selected determinants of the efficiency of healthcare to confirm the validity of their use. In the next stage, we determined the ranking of voivodeships, using the Data Envelopment Analysis method (an output-oriented model with constant returns to scale), according to the degree of their efficiency and outlined trends in the development of individual performance indicators within voivodeships. We completed the analysis by determining the sources of productivity changes between the first and last year of the study period with values such as 


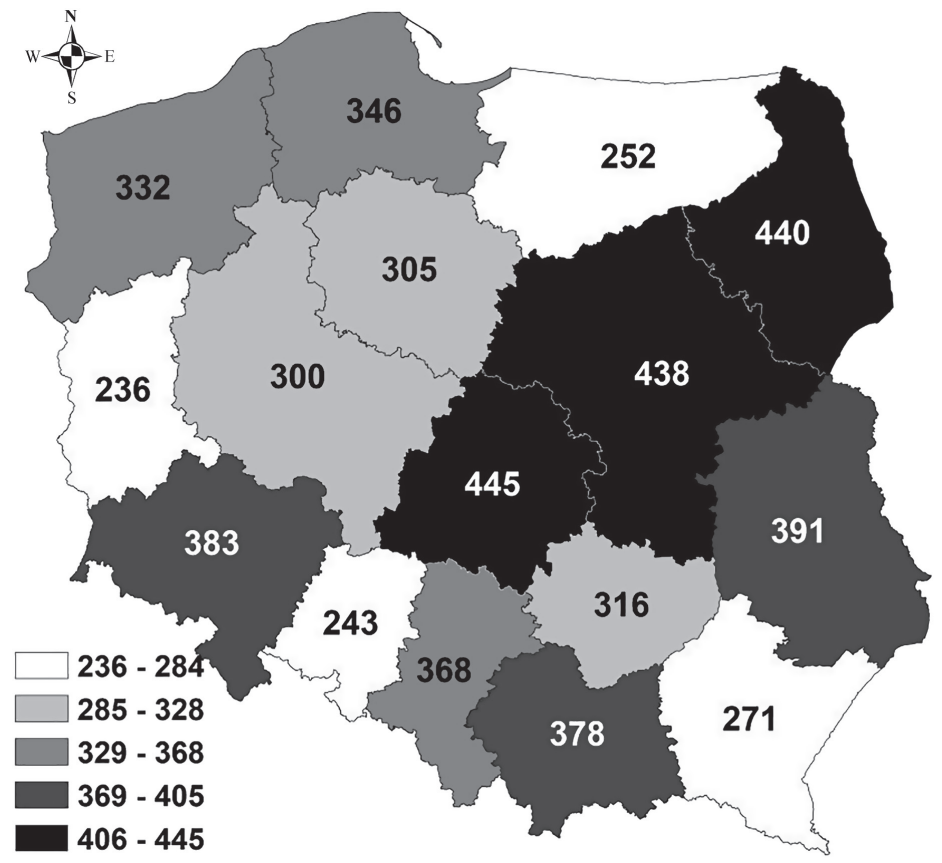

Source(s): Own elaboration
The efficiency of the healthcare sector in Poland

2749

pure technical efficiency change (TPE), scale efficiency change (scale) and technological efficiency (TE). Then, we incorporated the 2-years DEA window output-oriented model with constant returns to scale. Finally, using panel data econometric modeling, we determined the factors that have an impact on the previously estimated efficiency.

The choice of the orientation of the DEA model on outputs (Miclos et al., 2017; Stefko et al., 2018), rather than on inputs (Cordero Ferrera et al., 2014; Jewczak and Źółtaczek, 2011; Kujawska, 2018), was dictated by the literature review (Zakowska and Godycki-Cwirko, 2020). Taking into consideration that the hospital aims to provide services of the highest quality and in the shortest possible time while using the latest technologies, we focused our model on the outputs. Thus, with the aim of the functioning of the sector (understood from the perspective of the hospital) set in this way, the outputs of its functioning include the treatment and discharge of a large number of satisfied patients after therapy. Our approach has been confirmed, and thus, it is consistent with the literature on the subject (Cheng et al., 2016; Oikonomou et al., 2016; Stefko et al., 2018). In terms of selecting the return to scale, our analysis used a model with constant returns to scale. Such a decision was made based on defined goals, and, it was supported by solutions used in the literature on the subject (Adang et al., 2016; Madureira et al., 2013; Oikonomou et al., 2016; Stefko et al., 2018)

Initially, the DEA window analysis was based on three inputs and five outputs. The final selection of variables (Table 1) from the catalog presented in Figure 8 was supported by correlation analysis, based on which some variables, that were initially considered in the study, were removed. Therefore, we based our analysis on 16 voivodeships in six years, which altogether gave 96 observations. To overcome the relatively low number of observations, we decided to use DEA window analysis. The length of each window was calculated based on methodological guidelines (Cooper et al., 2007). 


\section{IJPPM \\ 71,7}

\section{0}

Figure 7.

The distribution of nurses in voivodeships

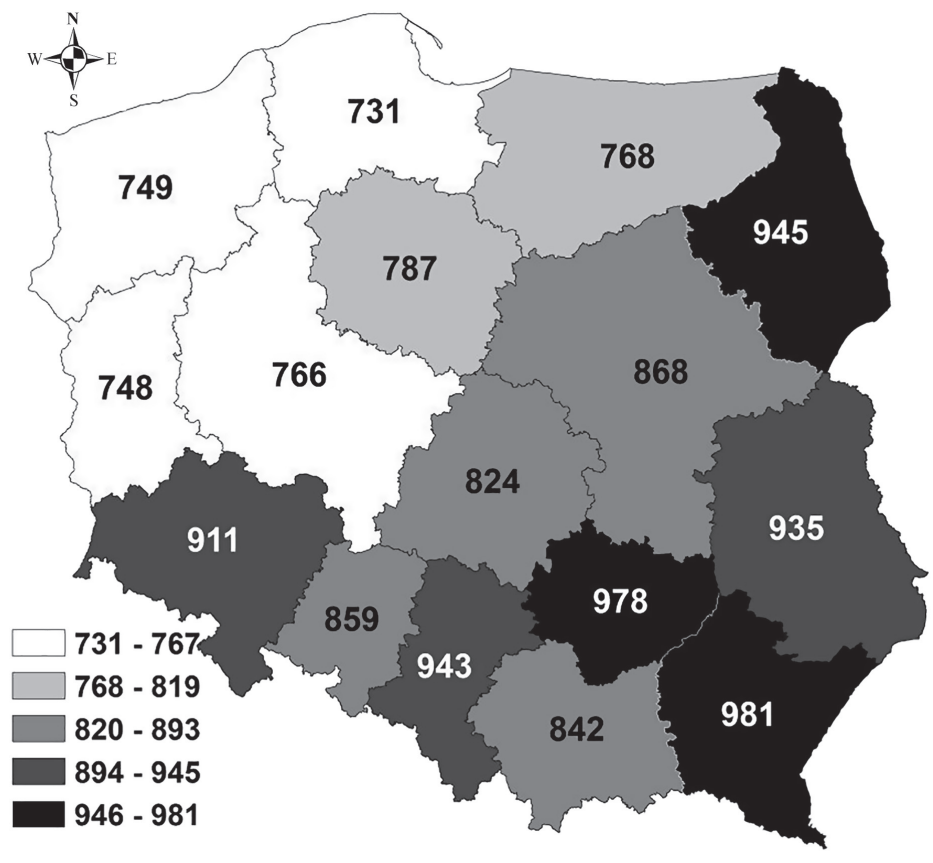

Source(s): Own elaboration

\section{Data Envelopment Analysis in efficiency measurement}

The Data Envelopment Analysis is a non-parametric linear programming method introduced by Charnes et al. (1978), who extended Farrell's idea and used this approach in multidimensional situations. It is derived from the concept of productivity, defined as the ratio of individual output to a single input (Charnes et al., 1994). "Virtual" outputs and inputs were created, which were the weighted sums of the actual outputs/inputs. The efficiency for the $k$ th decision making unit, DMU (in our case voivodeship) was defined as follows (1):

$$
E_{k}=\frac{Y_{k}}{U_{k}}
$$

where, $U_{k}$ - virtual output, $i, k$ - the number of input/output, $U_{k}=\sum_{i} \alpha_{i} \cdot x_{i, k}, Y_{k}$ - virtual input, $Y_{k}=\sum_{i} \beta_{i} \cdot y_{i, k}, \alpha_{i}$ and $\beta_{i}$ - weights concerning the importance of particular inputs/ outputs. Weights are determined to maximize the efficiency of DMUs (Birman et al., 2003).

DEA is a methodology used for testing the efficiency of economic entities, which refers to the construction of production function. It computes a comparative ratio of weighted inputs for every unit, called the relative efficiency score. The efficiency score is presented as a percentage or value between 0 and 1 (Avkiran and Rowlands, 2003). The DEA method has undergone several modifications and extensions. CCR (Charnes, Cooper, Rhodes) and BCC (Banker, Charnes, Cooper) are the two fundamental models. Both models can be adopted for a different orientation: input-oriented, output-oriented, and non-oriented models. At the same time, the CCR model is based on constant returns to scale (also known as CRS), while the latter is based on variable returns to scale (also known as VRS) (Jia and Yuan, 2017). The BCC model enables a further efficiency division based on purely technical efficiency and scale efficiency 


\begin{tabular}{ll}
\hline Label & Variable \\
\hline $\begin{array}{l}\text { Inputs } \\
\{\mathrm{I}\} 1\end{array}$ & $\begin{array}{l}\text { Share of health expenditure in } \\
\text { household revenues }\end{array}$ \\
& \\
$\{\mathrm{I}\} 2$ & Expenses for long-term care \\
$\{\mathrm{I}\} 3$ & Number of medical staff \\
$\begin{array}{ll}\text { Outputs } \\
\{\mathrm{O}\} 1 & \begin{array}{l}\text { Deaths to avoid in chronic obstructive } \\
\text { pulmonary disease }\end{array}\end{array}$
\end{tabular}

$\{\mathrm{O}\} 2$ Number of people on waiting lists

$\{\mathrm{O}\} 3$ Accreditation

$\{0\} 4$ The profitability of gross sales of selfgovernment hospitals in voivodships

$\{0\} 5$ EBITDA of local government units in voivodships

Source(s): Own elaboration
Definition

Household expenditure on protection health concerns expenses for medical services, medicines, and private medical insurance. These expenses also include forms characteristic of the Polish market, the so-called subscription fees - prepaid forms of health services that are on the border of health services and health insurance National Health Fund expenditure on long-term care per person over 75 years of age

Number of physicians per inhabitant

Compliant premature due to disease as a rule curable. It is, therefore, mortality which - in a given age range - can be prevented by incorporating health promotion, prevention, as well as proper diagnostic and therapeutic management and rehabilitation

The total number of people (stable cases) waiting to visit selected clinics (neurological, ophthalmic, cardiological, endocrine and traumatic orthopedic surgery) per 1,000 population

Number of hospitals in the voivodship with the accreditation of the Quality Monitoring Center in the total number of hospitals

The gross sales profitability indicator informs about the value of gross profit (before tax), falling for every PLN of achieved revenues. The indicator informs about the profitability of current operations of the entire group of entities with the status of hospitals in a given voivodship, except for those belonging to the Ministry of the Interior, Ministry of National Defense

Operating profit/loss + depreciation in local government units in the voivodship (excluding departmental and clinical units)
The efficiency of the healthcare sector in Poland

2751

Table 1.

Specification of DEA window variables

(Banker et al., 1984), while, as Jia and Yuan underline, CCR provides information concerning technical efficiency in practical use. The formal denotation of the output-oriented CCR model (with the assumption of constant returns to scale) states that for a given set of $n$ DMUs each one consumes $m$ inputs, denoted by $x_{i}(i=1,2, \ldots, m)$ and weight of inputs $v_{i}(i=1,2, \ldots m)$, to produce $q$ outputs, denoted by $y_{r}(r=1,2, \ldots, q)$ and weight of outputs $u_{r}(r=1,2, \ldots, q)$. The output-oriented efficiency of $o$ unit $\left(\theta_{0}\right)$ is given by the solution of the above linear programming problem (equations $2-5$ ):

$$
\begin{gathered}
\min \sum_{i=1}^{s} v_{i} x_{i j} \\
\sum_{r=1}^{s} \mu_{r} y_{r j}-\sum_{i=1}^{m} v_{i} x_{i j} \leq 0 \\
\sum_{i=1}^{q} \mu_{r} y_{r k}=1
\end{gathered}
$$




\section{IJPPM \\ 71,7}

\section{2}

Figure 8.

Group division of analyzed variables

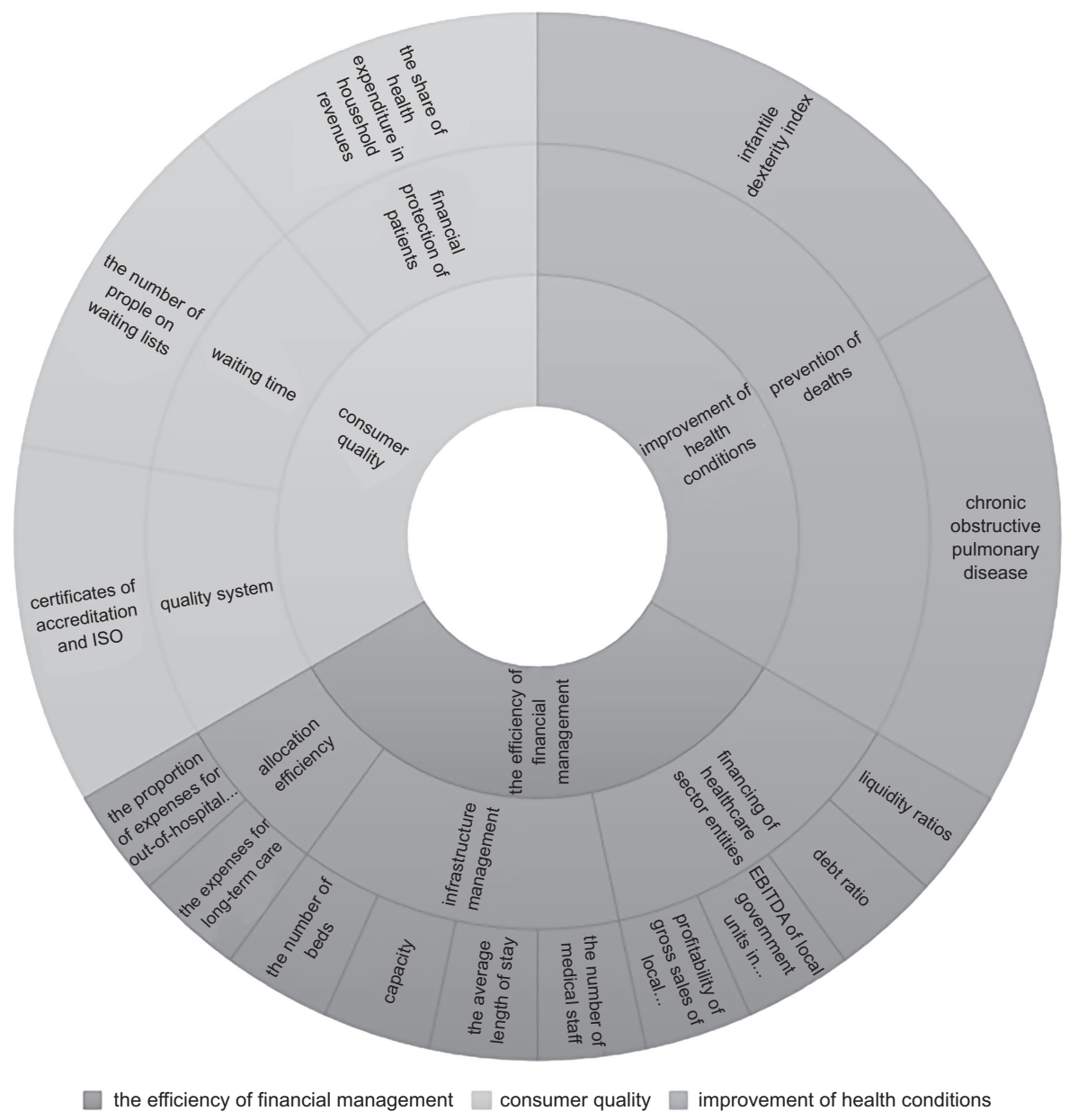

Source(s): Own elaboration

$$
\begin{gathered}
v_{i o}, \mu_{r o} \geq 0 \\
i=1,2, \ldots, m ; r=1,2, \ldots, q ; j=1,2, \ldots, n
\end{gathered}
$$

Its dual model (equations 7-11) is denoted as (Cheng, 2014):

$$
\max \theta_{o}
$$

$$
\begin{aligned}
& \sum_{i=1}^{m} \lambda_{j} x_{i j} \leq x_{i k} \\
& \sum_{j=1}^{n} \lambda_{j} y_{i j} \geq \theta y_{r k}
\end{aligned}
$$

$$
\lambda_{j} \geq 0
$$




$$
i=1,2, \ldots, m ; r=1,2, \ldots, q ; j=1,2, \ldots, n
$$

Incorporating the DEA method in efficiency analysis may have some disadvantages. As Sathye (2003) underlines, the main shortcoming of the DEA method is the relativity of efficiency measures. Efficient DMUs (examined in the sample) are efficient only in relation to other ones from that sample, which is why it is impossible to compare DMUs from different samples (Sathye, 2003). Another common problem of DEA implementation is the limited number of DMUs. To overcome these two drawbacks, a dynamic, instead of a so-called contemporaneous perspective, should be applied (Flokou et al., 2017). The solution to this problem is window - analysis, by which it is possible to measure the efficiency of a limited number of DMUs in individual periods and to analyze it over time. DEA window analysis generalizes the idea of moving averages to uncover the trend of DMU efficiency development trend over time (Stefko et al., 2018). Each DMU is considered a separate unit in individual periods in individual windows (Cooper et al., 2007). Hence the inputs and outputs in the selected period are compared to corresponding ones in all other periods. The appropriate determination of window size and length, along with the total number of different DMUs under the inference, were presented by Cooper, Seiford and Tone work (2007). The benefit of this method is both an increase in the number of DMUs (Jia and Yuan, 2017) and a full description of their dynamic changes, both horizontal and vertical (Stefko et al., 2018). Window analysis has been used to analyze devoted not only the healthcare sector (Flokou et al., 2017; Ghahremanloo et al., 2020; Kazley and Ozcan, 2009; O’Neill et al., 2008; Serván-Mori et al., 2018), but also the banking sector (Sufian, 2007; Webb, 2003), wood industry (Hemmasi et al., 2011) and port production (Cullinane et al., 2006), among others.

\section{Data source and sample characteristics}

In the study, the regional efficiency of the Polish healthcare sector was analyzed through the perspective of 16 voivodeships between 2013 and 2018. We have decided to monitor the units at the smallest possible regional level of tracking. That is why, to ensure the comparability and availability of data, we used the NUTS 2 division. Unfortunately, data at a lower level of aggregation - microdata - are not available. The analysis was carried out based on data provided by Price Waterhouse Coopers (PWC), which gathered data from: the Ministry of Health, the National Health Fund, the Quality Monitoring Center, the Central Statistical Office and their own analyses.

We analyzed three aspects of the efficiency of the healthcare sector within individual voivodeships: improvements in health conditions, consumer quality and the efficiency of financial management. We confirmed the application of this approach in PWC's Healthcare Efficiency Index (Kozierkiewicz et al., 2019) and in the research of Jacobs et al. (2013), who stated that including the aspect of improving the patient's state of health in the analysis, as well as the quality of services provided and financial management, is inevitable for a wellestablished study. It is worth noting that incorporating quality into DEA models is extremely problematic and requires an appropriate approach as quality can be perceived from various perspectives, that is assistance, perceived health, technical issues or accreditation/ certification. Therefore, the selection of variables in this area requires special attention and reference not only to the literature on the subject, but also to examining the relationship between the variables covered by the analysis. The validity of including selected variables in the analysis was confirmed by the literature review on the subject. The assignment of variables to individual groups is presented in Figure 8.

Within the area of financial management efficiency, the issues of financing health services from the perspective of the service provider and recipient, personnel, and fixed assets management, as well as financial results of medical facilities, are raised. Hence, according to
The efficiency of the healthcare sector in Poland 
IJPPM 71,7

Baray and Cliquet (2013), the number of medical staff considered as the number of doctors constitutes the primary indicator used in monitoring the economic outturn (Ferrier and Trivitt, 2013; Liu et al., 2016; Stefko et al., 2018). What is more, together with the number of hospital beds, it also reflects the size of the patient's catchment area (Stefko et al., 2018). Stefko et al. (2018) also rightly noted that each added bed allows the hospital and, therefore, voivodeships, to provide medical services, increasing marginal profit for the healthcare unit. On the other hand, it also generates additional costs that should be covered by the primary payer; in Poland, it is - the National Health Fund. According to the literature review, the number of hospital beds is widely used in national comparisons of healthcare services (Byrnes and Valdmanis, 1994; Hollingsworth and Peacock, 2008; Ley, 1991; Magnussen and Nyland, 2008; Mitropoulos et al., 2013). Comparisons between countries that use this indicator were carried out by Varabyova and Schreyogg (2013) and Samut and Cafri (2016). It was also used in micro-scale comparisons, for example, by Wang et al. (2016) to compare child health hospital services.

Capacity is used to denote the number of patients treated in hospitals in relation to the number of hospital beds. It is connected with the cost-generating sphere of hospitalization and is associated with the average length of patients' stay. While capacity is being reduced, the total cost is also being reduced due to the fall in the costs of hospitalizations (Stefko et al., 2018). Stefko et al. also underlined that a low average length of stay implies more demanding and, as a consequence, more expensive healthcare. On the other hand, discharging patients too quickly may result in re-hospitalization, which in most cases generates even higher costs than those during the patient's initial admission. Those two variables are widely used when examining healthcare efficiency (Miszczyńska, 2019; Stefko et al., 2018; Varabyova and Schreyögg, 2013).

The financial aspect of healthcare functioning is frequently touched on in comparisons of both healthcare systems and hospitals. In, micro terms, indicators relating to the financial analysis of healthcare entities are very often used, and in macro terms, those related to expenditure transferred to health services are used. The latter can be considered from the primary wage (recognized in the form of spending on hospital treatment or long-term care) and household (e.g., expenditure on household health) perspectives. In that context, Czypionka et al. (2014) analyzed hospitals from the perspective of their efficiency, financing and ownership. Bastian et al. (2016) examined the impact of hospital efficiency on wellness in the Military Health System. A cost and performance comparison of public-private partnership and public hospitals was conducted by Caballer-Tarazona and Vivas-Consuelo (2016). They incorporated a financial aspect to study the effect of strategic hospital alliances on hospital efficiency. Bem et al. (2015) examined the relationship between hospital profitability and debt ratios. The main objective of this study was to investigate whether, in the absence of sufficient profits from operating activities, hospitals use debt as a source of funding. The research led to the statement that hospitals characterized by low profitability were more heavily indebted than those with high profitability ratios. Cygańska (2015) also did a profitability assessment aimed to verify whether there was a statistical difference between the financial situation of hospitals operating in the form of capital companies and those that were becoming independent public healthcare institutions. No statistically significant relationship between the size of the hospital and the moment of its transformation was observed. Moreover, in her latest research, Cygańska developed a new measure the clinical efficiency index - which can be used to evaluate a hospital's operational efficiency based on both costs and clinical factors (Cygańska, 2019). The study showed that conclusions drawn from the financial analysis differ when covering clinical aspects. DubasJakóbczyk et al. (2020) did a cross-sectional study on the financial performance of Polish hospitals, analyzing the relationship between financial performance and particular variables. 
The quality of services provided, which is a significant area in efficiency assessment and measurement, can also be examined from different perspectives - the entire system and individual units. One measurable effect of the quality of the functioning of the sector is the high percentage of entities that hold accreditation certificates. On the other hand, there are waiting lists for some medical procedures (Akinci and Patel, 2014; Akram et al., 2017; Kapoor, 2011; Kenny, 2015; Miszczyńska, 2018a; Miszczyńska and Antczak, 2020; Sajid and Baig, 2007).

Improving health seems to be one of the fundamental indicators for efficiency assessment. One of the most crucial indicators by which the measurable effect of a well-functioning healthcare system can be assessed is the mortality rate (English et al., 2018; Kruk et al., 2018; Tambeur et al., 2019). It can be considered in the form of an infantile dexterity index, or, for example, compliance rates to be avoided for reasons of various diseases, such as chronic obstructive pulmonary disease.

\section{Empirical results and discussion \\ Data Envelopment Analysis - the results}

The efficiency of healthcare services in 16 Polish voivodeships was analyzed using the DEA output-oriented efficiency model with the assumption of constant returns to scale (the CCR model) between 2013 and 2018. The variables (inputs/outputs) that relate to the efficiency of the healthcare sector that were chosen for the analysis were collected and descriptive statistics were examined (Table 2). From the descriptive statistics, we observed that in the case of almost all outputs, the maximum is approximately from three up to ten times higher compared to the minimum in each year. This indicated that the size of the regional distribution was significant and that the voivodeships varied in terms of the examined variables. The biggest differences across the variables were for accreditation $\{\mathrm{O}\} 3$ and operating profit/loss (EBIDTA) $\{\mathrm{O}\}$ 5. There was a huge spread in the level of funding within the voivodeships. The variable "the number of medical staff" was also worth an in-depth analysis. In this variable right-side skewness was observed, which indicated that there were voivodeships in which the number of medical staff per inhabitant was far bigger than the mean value.

Based on the results of the CCR model, we ranked the voivodeships according to their efficiency. The results of this analysis outlined trends in the development of individual performance indicators within voivodeships. Some voivodeships that were efficient throughout the entire period were identified, including, Lubelskie, Lubuskie, Lodzkie, Malopolskie, Podlaskie and Swietokrzyskie. Extending our analysis, we identified the sources of productivity change between the first and last year of the study period by determining pure technical efficiency change (TPE), scale efficiency change (scale), and technological efficiency (TE). According to the results presented in Figure 9 and Figure 10, both PTE and scale improved. In general, mean pure technical efficiency was found to span a range of values from $97.22 \%$ in 2013 to 98.26 in 2018. Mean scale efficiency was also found within the range of $96.08 \%$ in 2013 and $98.13 \%$ in 2018 .

To make the analysis complete, we incorporated an output-oriented 2-years window DEA model (with constant returns to scale), and therefore, five overlapping windows were analyzed over the 6-years study. The literature confirms that such a narrow width of windows is an advantage of the procedure. According to Flokou et al. (2017), it provides the minimum common ground that allows a year-to-year efficiency comparison without the probable distortion that a wider window would have imposed. It is also beneficial for the analysis because it increases the number of voivodeships in the window. Considering a small number of voivodeships, this proves to be a very desirable feature. Before using the DEA model, special care was taken to ensure the correct direction of preferences. Thus, the results were treated as stimulants and the inputs as destimulants. The average year-specific and window-specific CRS model efficiency results are presented in Table 3 in which: 


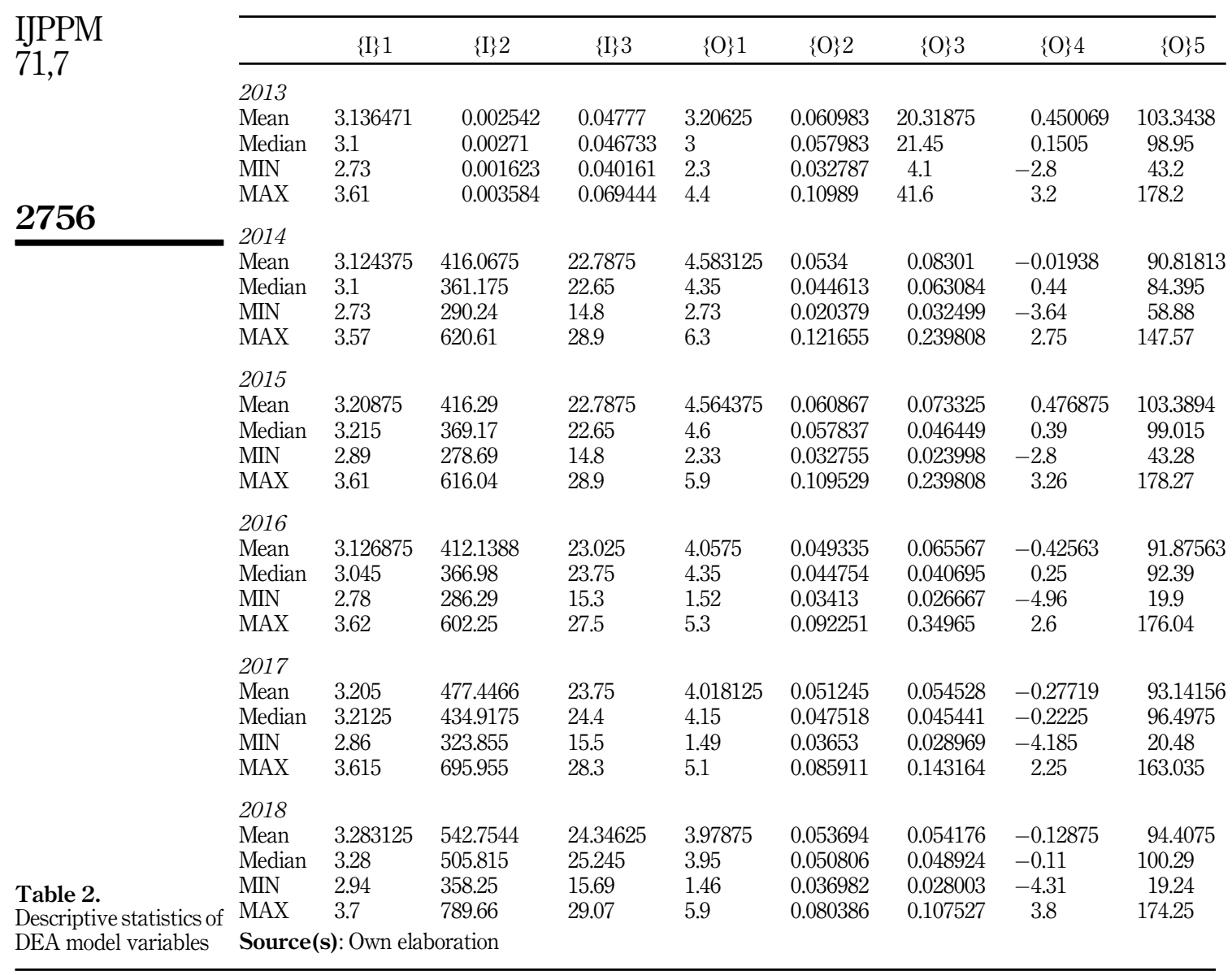

(1) Rows represent window width,

(2) Intersections of a row and a column present an efficiency score in the context of a year within a specific window

Moreover, vertical changes provide an indicator concerning the stability of the results for each year across the two different windows. That is why, based on "row analysis," the efficiency trends of the voivodeships can be observed. The results presented in Table 3 showed some room for improvement in terms of units' efficiency. The lowest and highest levels of efficiency were 93.43 and $98.15 \%$, respectively. The spreads between the highest and the lowest efficiency scores in the windows in question do not vary significantly, which is presented by standard deviation results. Moving on to the results concerning average yearspecific and window-specific efficiency scores, considerable room for improvement is also suggested. To be more specific, the lowest and highest year-specific mean efficiency scores are still far from the $100 \%$ efficiency level. However, a significant increase has been noticed. The detailed results of the 2-years-window showed the lowest efficiency scores in the window: 2014-2015. 


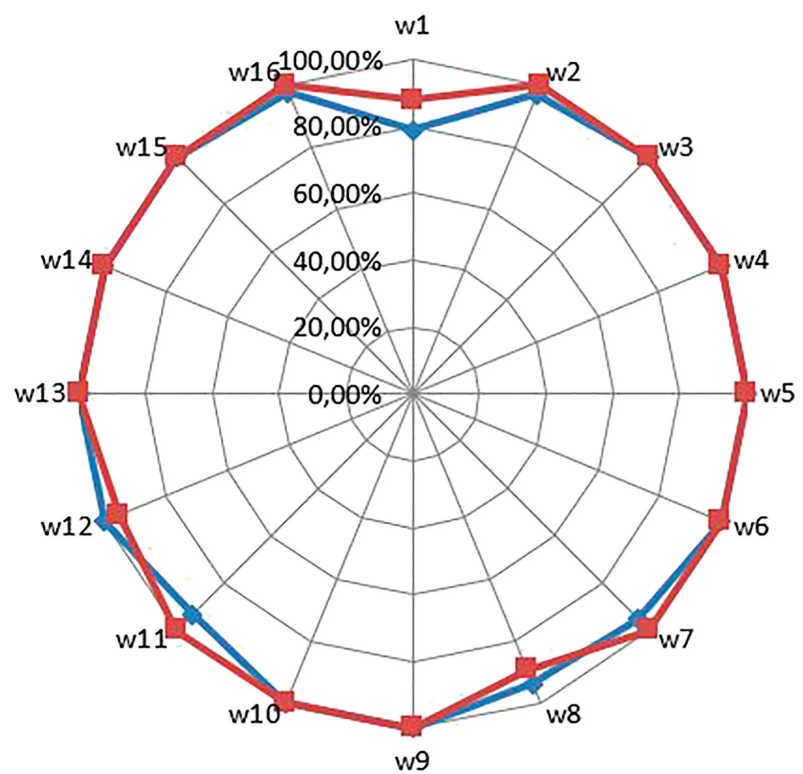

Source(s): Own elaboration

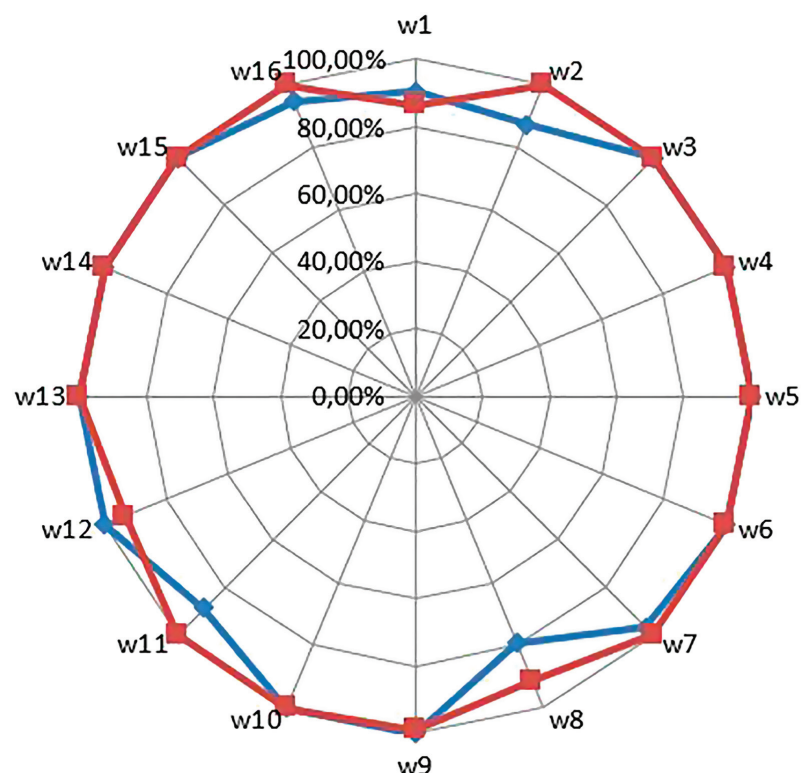

Source(s): Own elaboration
The efficiency of the healthcare sector in Poland

$\leadsto$ PTE 2013

- - PTE 2018

$\leadsto$ Scale 2013

- Scale 2018
Figure 9. Pure technical efficiency results
Figure 10. Scale efficiency results 


\begin{tabular}{|c|c|c|c|c|c|c|c|c|}
\hline $\begin{array}{l}\text { IJPPM } \\
71,7\end{array}$ & & 2013 & 2014 & 2015 & 2016 & 2017 & 2018 & $\begin{array}{c}\text { Entire window } \\
(N=32)\end{array}$ \\
\hline 2758 & $\begin{array}{l}\text { Mean CRS effic } \\
2013-2014 \\
2014-2015 \\
2015-2016 \\
2016-2017 \\
2017-2018 \\
\text { Common year }\end{array}$ & $\begin{array}{l}n c y \\
93.59 \% \\
\end{array}$ & $\begin{array}{l}95.65 \% \\
95.65 \%\end{array}$ & $\begin{array}{l}93.43 \% \\
93.43 \%\end{array}$ & $\begin{array}{l}96.78 \% \\
96.78 \% \\
96.78 \%\end{array}$ & $\begin{array}{l}96.76 \% \\
97.46 \% \\
97.11 \%\end{array}$ & $\begin{array}{l}98.15 \% \\
98.15 \%\end{array}$ & $\begin{array}{l}94.62 \% \\
94.54 \% \\
95.11 \% \\
96.77 \% \\
97.80 \%\end{array}$ \\
\hline & $\begin{array}{l}\text { Standard Devia } \\
2013-2014 \\
2014-2015 \\
2015-2016 \\
2016-2017 \\
2017-2018 \\
\text { Common year }\end{array}$ & $9.91 \%$ & $\begin{array}{l}6.87 \% \\
6.87 \%\end{array}$ & $\begin{array}{l}9.83 \% \\
9.83 \% \\
\\
9.83 \%\end{array}$ & $\begin{array}{l}5.96 \% \\
5.96 \% \\
5.96 \%\end{array}$ & $\begin{array}{l}6.77 \% \\
4.62 \% \\
5.70 \%\end{array}$ & $\begin{array}{l}5.43 \% \\
5.43 \%\end{array}$ & $\begin{array}{l}10.60 \% \\
10.70 \% \\
10.80 \% \\
11.10 \% \\
10.10 \%\end{array}$ \\
\hline $\begin{array}{l}\text { Table } 3 \text {. } \\
\text { Mean CRS results }\end{array}$ & $\begin{array}{l}\text { Number of effic } \\
2013-2014 \\
2014-2015 \\
2015-2016 \\
2016-2017 \\
2017-2018 \\
\text { Source(s): Ow }\end{array}$ & $\begin{array}{l}\text { ncy units } \\
10 \\
\text { elaboration }\end{array}$ & $\begin{array}{l}10 \\
10\end{array}$ & $\begin{array}{l}10 \\
10\end{array}$ & $\begin{array}{l}11 \\
11\end{array}$ & $\begin{array}{l}11 \\
11\end{array}$ & 12 & $\begin{array}{l}20 \\
20 \\
21 \\
22 \\
23\end{array}$ \\
\hline
\end{tabular}

The window analysis was complemented by the study of trends for individual voivodeships together with a detailed analysis of changes in the efficiency levels of the examined voivodeships. The results are presented in Table 4 . Hence, some abbreviations have been applied: "I," "D," and "CONST," denoting, respectively, an increase, decrease, or steadiness in voivodeships efficiency. The last symbol indicates the transition from a fully efficient unit to an also fully efficient unit. As mentioned above, within the whole analyzed period, some fully efficient units were detected. Some of them (Malopolskie, Podlaskie and Swietokrzyskie) were also efficient in all analyzed windows. Moreover, " $+\mathrm{D}$ " referred to an efficiency deterioration, which led from a fully efficient unit to a non-efficient unit, while "I+" denoted a transformation from a non-efficient unit to a fully efficient one. As Table 4 clearly shows, six voivodeships improved their healthcare efficiency and became fully efficient units, while five units suffered a decrease in efficiency and became ineffective.

Determinating the factors that affect efficiency - panel data econometric modeling

After determining the efficiency indicators, the last element of the analysis was to determine the factors that influence it. For this purpose, panel data modeling was used. The analysis covered the years 2013-2018. The dependent variable was the efficiency index calculated using the DEA method (based on the output-oriented super-efficiency DEA model). For explanatory variables the following set was chosen (for description, see Table 1):

(1) exp_house - the share of health expenditure in household revenues - $\{I\} 1$ - negatively correlated with the dependent variable;

(2) exp_long_term - the expenses for long-term care - $\{\mathrm{I}\} 2$ - negatively correlated with the dependent variable;

(3) med_staff - the number of medical staff - $\{\mathrm{I}\} 3$ - negatively correlated with the dependent variable; 


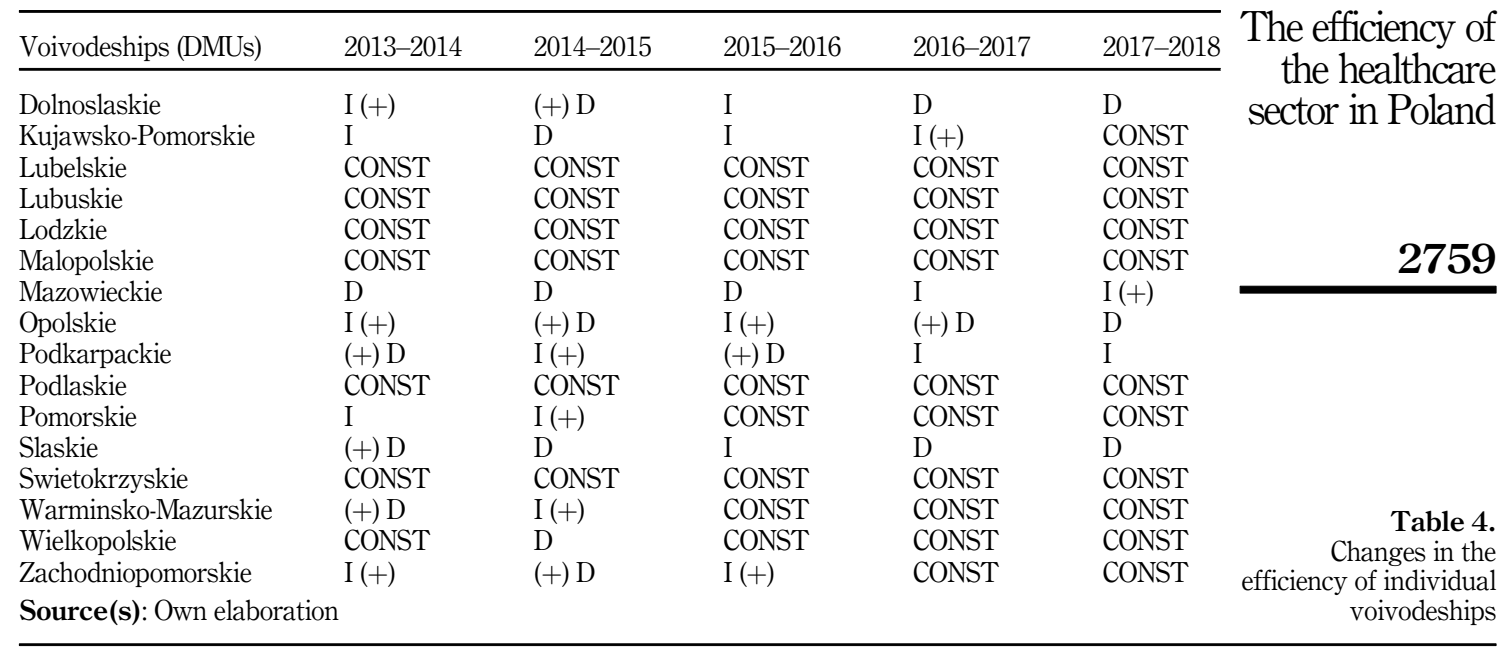

(4) death_copd - deaths to avoid in chronic obstructive pulmonary diseases - $\{0\} 1-$ positively correlated with the dependent variable;

(5) num_wist - the number of people on waiting lists - $\{0\} 2$-negatively correlated with the dependent variable;

(6) acc - certificate of accreditation - $\{0\} 3$ - positively correlated with the dependent variable;

(7) profit - the profitability of gross sales of self-government hospitals in voivodeships $-\{\mathrm{O}\} 4$ - positively correlated with the dependent variable;

(8) ebitda - EBITDA of local government units in voivodeships - $\{\mathrm{O}\} 5$ - positively correlated with the dependent variable;

Before applying panel modeling, the correlations between the variables were checked. The appropriate estimation procedure was determined based on the assumptions regarding constancy or randomness of group and time effects, i.e. the appropriate pooled model, fixed effects (FEM) or variable effects (REM) model was selected. The stationarity of the variables was also checked using the Levin-Lin-Chu test. In order to preserve it, modeling was performed based on appropriately transformed variables (see Table 5). Therefore, a pooled estimation model was used to estimate factors that affect the efficiency of the healthcare sector. Table 6 presents the tests confirming the validity of the applied form of panel modeling. As a result of the modeling, while maintaining the knowledge about the correlation of the variables, variable $\{I\} 1$ was excluded from the analysis. The modeling results are presented in Table 7. Referring to the results, all variables included in the modeling received an economically desirable sign when estimating the parameters. As a result of the correlation analysis, the share of health expenditure in household revenues (exp_house variable) was excluded because it correlated with other explanatory variables. The modeling showed that the efficiency of the healthcare sector in individual voivodeships was not significantly influenced by deaths avoided in chronic obstructive pulmonary disease and EBITDA of voivodeships.

\section{Discussion}

Adapting a public health policy to a rapidly changing environment seems to be the most serious challenge for policy-makers in recent years. Thus, assessing the healthcare sector's 


\section{IJPPM 71,7}

\begin{tabular}{|c|c|c|c|c|}
\hline Variable & Method & Statistic & $p$-value & $\begin{array}{l}H_{0}: \text { Panels contain unit roots } \\
H_{1}: \text { Panels are stationary } \\
\end{array}$ \\
\hline $\begin{array}{l}\text { Ld_EF } \\
\text { ld_exp_long_term } \\
\text { ld_med_staff } \\
\text { ld_death_copd } \\
\text { ld_num_wist } \\
\text { ld_acc } \\
\text { ld_profit } \\
\text { ld_ebitda }\end{array}$ & Levin-Lin-Chu & $\begin{array}{l}-1.569 \\
-0.6686 \\
-1.6026 \\
-0.92942 \\
-1.2484 \\
-1.4355 \\
-0.67082 \\
-1.4284\end{array}$ & $\begin{array}{l}0.0000 \\
0.0001 \\
0.0000 \\
0.0000 \\
0.0000 \\
0.0000 \\
0.0034 \\
0.0000\end{array}$ & $\begin{array}{l}H_{1} \\
H_{1} \\
H_{1} \\
H_{1} \\
H_{1} \\
H_{1} \\
H_{1} \\
H_{1}\end{array}$ \\
\hline \multicolumn{2}{|c|}{$\begin{array}{l}\text { ld_ebitda } \\
\text { Source(s): Own elaboration }\end{array}$} & & & \\
\hline
\end{tabular}

Table 5.

Stationarity testing

\begin{tabular}{ll}
\hline Hypotheses & Tests \\
\hline $\mathrm{H}_{0}:$ is the OLS model & Wald \\
$\mathrm{H}_{1}$ : is the RE model & $F=1.30355$ with $p$-value $=0.316033$ \\
\hline Hypotheses & Tests \\
\hline $\mathrm{H}_{0}:$ is the OLS model & Breusch-Pagan \\
$\mathrm{H}_{1}:$ is the FE model & LM $=0.25437$ with $p$-value $=0.614015$
\end{tabular}

Table 6.

Note(s): OLS - ordinary least squares, RE-random effects model, FE-fixed effects model, df-degrees of Diagnostic tests for the Significance levels: $\alpha=0.10^{*}, 0.05 * *, 0.01 * * *$ panel data model

Significance levels: $\alpha=0.10^{*}$
Source(s): Own elaboration

Panel pooled estimation

Time series length: 6

Dependent variable (Y): ld_EF

Robust HAC estimation

\begin{tabular}{lcccc} 
& Coefficient & St. dev. & $t$-student & $p$-value \\
\hline const & 0.182559 & 0.0483942 & 3.772 & $0.0036^{* * * *}$ \\
ld_exp_long_term & -1.31900 & 0.435889 & -3.026 & $0.0128^{* *}$ \\
ld_med_staff & -1.12161 & 0.212049 & -5.289 & $0.0004^{* * * *}$ \\
ld_death_copd & 0.0528789 & 0.183610 & 0.2880 & 0.7792 \\
ld_num_wlist & -0.576100 & 0.219187 & -2.628 & $0.0252^{* * *}$ \\
ld_acc & 0.551036 & 0.120137 & 4.587 & $0.0010^{* * *}$ \\
ld_profit & 0.0946474 & 0.0399435 & 2.370 & $0.0393^{* *}$ \\
ld_ebitda & 0.177038 & 0.173510 & 1.020 & 0.3316
\end{tabular}

Note(s): $\mathrm{VIF}<10.0$ $R^{2}=0.6435$

Table 7.

Residuals normality test, $\chi^{2}=4.806$ with $p$-value $=0.9044(\mathrm{df}=2)$

Estimation results

Significance levels: $\alpha=0.10^{*}, 0.05^{* *}, 0.01^{* * *}, \mathrm{df}-$ degrees of freedom

Source(s): Own elaboration

efficiency seems to be inevitable. A healthcare sector that is organized and performs well is vital not only from the perspective of patient satisfaction but also from the standpoint of managers. Efficiency analysis, as one of the main criteria of performance assessment, is 
considered by scientists not only in the context of financial decision making (Jena and Philipson, 2013; Knapp et al., 2012; Willan and Kowgier, 2008) but also other managerial aspects (Journard et al., 2010; Vanberkel et al., 2012). Thus, analyzing the efficiency of the healthcare sector in Poland was fully justified. The analysis of the healthcare sector can be conducted by analyzing a given country as a whole or from the perspective of the country's administrative divisions. Thus, we decided to analyze it from the perspective of 16 voivodeships. This approach is fully justified and supported by the literature (Miszczyńska, 2018b; Pelone et al., 2012; Stefko et al., 2018), as voivodeships significantly affect the shape of the entire sector in Poland. They not only organize the system, but as the founder public hospitals, they are simultaneously healthcare providers. Thus, they have a huge impact on shaping solutions aimed at the more efficient functioning of a wide range of processes. Their tasks to ensure equal access to healthcare services financed from public funds are presented in the Act on healthcare services financed from public funds of August 27, 2004. According to this act, the voivodeships (and other types of local government units) must perform tasks that include initiating, supporting, and monitoring the activities of the local government community regarding health promotion and health education, and they must stimulate actions for individual and collective responsibility for health protection.

The analysis of the data covered by our inference showed that the number of hospital beds did not fluctuate significantly over the analyzed years, although there was a slight downward trend related to the country's policy regarding the optimal number of beds in hospitals. The rationalization of the number of hospital beds was carried out in units where the use of the bed during the year did not exceed the level suggested by the Ministry of Health. However, as emphasized by Kuszewski et al. (2014), the main indicator should be the determination of the structure and number of hospital beds in relation to the supply of health services and the availability of healthcare products, not only to the number of beds. They also pointed out that there are significant differences in the distribution of hospital beds between hospitals, and thus also between regions, and there is clear regional asymmetry dictated by both the insufficient bed base and its hypertrophy. The results of our research also supported this. In 2018, there were 55 beds per 100 population in the Pomorskie voivodeship and only 44 in Malopolskie. Compared to 2013, in 2018, there was an increase in the rate of bed use recorded in half of the voivodeships. The highest increase was recorded in the Slaskie voivodeship, with almost 38 out of 47 patients treated per hospital bed. It was certainly related to the increase in the number of medical staff and specialist medical equipment in these voivodeships, as well as implemented health programs. It also resulted in an improvement in the health of residents in terms of avoidable deaths and a reduction in infant mortality.

The analysis of the efficiency of healthcare services in Polish voivodeships carried out using the DEA output-oriented model was based on the assumption of constant returns to scale. This model allowed us to rank units according to their efficiency. The results outlined trends in the development of individual performance indicators within individual voivodeships. We identified voivodeships that were efficient throughout the entire period. These included, among others, Lubelskie, Lubuskie, Lodzkie, Malopolskie, Swietokrzyskie or Podlaskie. These results are consistent with the results of the research presented by Miszczyńska (2018b), in which Malopolskie was assessed as efficient and constituted a benchmark for other, inefficient voivodeships. The results of the 2019 Healthcare Efficiency Index report in Poland (Kozierkiewicz et al., 2019) also confirmed the high position of the Malopolskie voivodeship. The remaining results are not analogous, and the discrepancies that arose resulted from the analysis of the sector's functioning based on a larger number of more detailed indicators. Nevertheless, the results of our analysis, as in the case of the Kozierkiewicz et al. report (2019), also led us to draw similar conclusions regarding the functioning of the healthcare sector in the aspects presented in Figure 8 . What is more, in our research, we positively assessed the trend of patients' improving assessment of access to 
IJPPM 71,7

doctors and diagnostic tests, a slight decrease in the number of people registered on waiting lists for specialist doctors (also confirmed in the Supreme Chamber of Control, 2019), and a slight increase in the number of units not requiring accreditation. Accreditation certification is an extremely important determinant of the quality of services provided by a medical entity. In the literature on the subject, it is noted that accredited hospitals, obtain ISO certification relatively easily, but vice versa, which is related to the standards that a given unit must meet (Miszczyńska, 2019). Accreditation may bring greater financial benefits to a hospital, allowing it to apply for higher contracts with the National Health Fund (Ministry of Health, 2020). Furthermore, since 2018, the National Health Fund has paid accredited hospitals extra (Miszczyńska and Antczak, 2020).

The efficiency analysis carried out using the DEA method allowed for further analysis to determine the factors that influence the efficiency of healthcare in Poland. Based on the econometric modeling, we distinguished the variables that have a statistically significant impact on the efficiency of healthcare services. Taking into account the short time series, it was necessary to conduct a panel analysis. The conducted inference allowed us to notice that one of the factors that influence efficiency was expenses for long-term care. These are expenses borne by the National Health Fund for long-term care for people over the age of 75 . As long-term care in Poland is underdeveloped and underfinanced, many people do not have adequate care. They use up hospital resources, resulting in costs that are disproportionate to the actual needs. Therefore, higher expenditure on long-term care make it more accessible (Kozierkiewicz et al., 2019). However, in terms of our study, it should be noted that few departments or units deal with long-term medical care compared to units with a different specialty. The healthcare sector in Poland is largely underfunded (Dubas-Jakóbczyk et al., 2020; Miszczyńska, 2020), so allocating more money to long-term care would be at the expense of basic care. Thus, from the perspective of the efficiency of healthcare services, increasing expenditure on this cost category translates into a reduction in the efficiency of the entire sector.

Another variable that influence the efficiency of healthcare was the number of doctors working in healthcare units (variable: med_staff). According to the modeling results, the efficiency of the healthcare system decreases with an increase in the number of doctors. Medical staff plays a crucial role in terms of patient care, but they also generate very high costs for healthcare facilities (Miszczyńska and Miszczyński, 2020). Thus, in order to increase efficiency, it would be necessary to invest in improving the qualifications of medical personnel, and not in hiring new specialists. From the perspective of improving efficiency, it seems desirable that patients could be treated more effectively with the same, not an increasing number of doctors.

The number of people waiting for a given medical service (variable: $n u m \_w l i s t$ ) also affects healthcare efficiency. The literature on the subject indicates that the number of people waiting is not a precise measure of waiting lists or a precise indicator of the shortage in the number of services (Kozierkiewicz et al., 2019), and there are many doubts as to the credibility or usefulness of this information. Nevertheless, as the legal conditions for keeping waiting lists are harmonized across the country, this figure may give a picture of the restriction of access to services in a specific pool of clinics. Thus, the model we have built shows that as the number of people waiting for medical services increases, efficiency decreases. This is a fully justified mechanism. However, the problem lies not only in the inefficiency of the treatment system, but also in the organization of referrals to these services (Dubas-Jakóbczyk et al., 2020). The main problem is that a patient may sign up on the waiting list in several different places, thus blocking other needy patients' registration.

The accreditation certificate is a very important element of quality management in healthcare. This was also reflected in our model, according to which an increase in the percentage of hospitals with accreditation in a given year increases the efficiency of 
healthcare services. Obviously, obtaining accreditation does not automatically guarantee high quality, but it is widely recognized that applying for accreditation is an expression of interest in quality issues by the management of a facility (Kozierkiewicz et al., 2019). Thus, obtaining accreditation should increase the probability of providing better quality services (Dubas-Jakóbczyk et al., 2020). Better quality translates into higher efficiency, which has been confirmed by our study.

The last variable in the model which proved to have a statistically significant impact on the dependent variable was gross profitability of sales (variable: profit). An increase in this ratio increases efficiency revenues. This means that to achieve a certain amount of profit, an entity must achieve lower sales. On the other hand, in terms of the healthcare sector, the sales profitability of the entire sector thus informs what profits or losses are generated by medical activities in relation to the scale of revenues of this sector. Thus, the higher the profitability, the higher the efficiency of the entire sector.

As Onen and Sayin (2018) underlined, the distribution, accessibility, and quality of healthcare determine the level of the quality of people's life. Based on the observed increase in healthcare costs in OECD countries (Onen and Sayin, 2018), a higher emphasis should be put on the evaluating healthcare entities and the organizational aspect of the healthcare sector (Khushalani and Ozcan, 2017). Onen and Sayin's view is particularly pertinent, not only in the case of Poland, but also other countries that have recently been or are still subject to continuous reforms of the healthcare system. Research in this area in terms of regions has also been conducted in Slovakia (Stefko et al., 2018), the Czech Republic (Blatnik et al., 2017; Kinkorová and Topolčan, 2012; Votápková and Štastná, 2013) and Slovenia (Blatnik et al., 2017; Lamovšek and Klun, 2020). We believe that these studies are extremely valuable in terms of their conclusions, particularly for countries that underwent reforms after the fall of communism in 1989. The methods used in these studies and the conclusions drawn from them may contribute to introducing similar changes in public policy with the scope of organizing and financing the healthcare sector. Thus, from the Polish perspective, special attention should be paid to analyses carried out in countries such as Bulgaria, Croatia, Czechia, Estonia, Hungary, Lithuania, Romania, Slovakia and Slovenia. Those countries reformed their systems solutions at the end of the 20th century or are still in the process of transforming their universal health insurance model.

\section{Conclusions}

The healthcare sector in Poland has been undergoing constant reforms since the end of the 19 th century. These changes were aimed at improving the efficiency of the sector, which would also improve the quality of patients' lives in the long term. In the short-term, the healthcare system should provide services of the highest quality in the shortest time possible. Due to the way services are administered in Poland, the healthcare system is very often analyzed from a regional perspective, for example voivodeships, poviats or communes. Voivodeships, poviats and communes, being local government units, have their own tasks, which are regulated by laws at the national level as well as by acts of local legislation (resolutions of relevant local government units). The role of local governments in health protection and promotion can be considered in three areas: the system organizer, the owner of health care units and the implementor of public health tasks (Tubek, 2010).

The fact that healthcare expenditures represent a substantial share of public expenditure puts significant pressure on rationalizing costs. To this end, in the last decade, the Ministry of Health has implemented an ongoing program of reforms in the public hospital sector. Although the system has changed significantly twice in that period, no major improvement has been noticed. Thus, extensive monitoring of healthcare sector efficiency seems inevitable.

The in-depth literature review justified the application of the DEA window analysis. Taking into account not only the principles of providing, financing, and accounting for health 
IJPPM 71,7

services, as well as the aspect of the ownership structure of public hospitals, it seems fully justified to conduct a study from a regional perspective. The analysis focused on showing regional disparities using a 2 -years window analysis. The conducted study presented an intertemporal efficiency scheme for the technical performance of Polish voivodeships in terms of healthcare. The findings showed that some voivodeships were efficient in all the years, according to the CCR findings. In the context of the window analysis, the study identified individual efficiency trends together with "all-windows" best and worst performers. It revealed that a high level of pure technical and scale efficiency were maintained over the entire period. However, it should be underlined that, neither the scale efficiency nor the technological change had improved in 2018 compared to 2013. Moreover, the voivodeships' situation was not stable, as evidenced by fluctuations in the value of the efficiency indicators. It was frequently observed that some units gained and immediately afterward lost efficiency in the analyzed period. Hence, the spatial diversity in the efficiency of voivodeships was confirmed. The study revealed that it is particularly important to notice and consider changes aimed at ensuring equal access to health services in the analyzed regions. Over-intensification results in specific systemic failures in some regions at the expense of others. The results also made it possible to identify the factors that influence the efficiency of the healthcare services sector. The catalog of these factors includes those relating to healthcare expenses, the length of waiting lists, medical personnel, accreditation and the profitability of medical units. The determination of factors that influence efficiency of the healthcare sector is extremely important because it shows the areas that should be improved. These factors may also indicate the directions of changes in the healthcare sectors of countries with the same or similar health system design (Czech Republic, Slovakia, Hungary).

As far as the study's limitations and future research are concerned, a more detailed analysis would be of great value. We believe that conducting the analysis at the voivodeship level was fully justified; however, a lower level of data aggregation, for example from the perspective of communes or the hospitals themselves, would reveal important information regarding the difficulties faced by healthcare entities in Poland. It would also be extremely important to conduct a comparative analysis of the efficiency of countries that reformed their systems at the end of the 20th century or that are still in the process of transformation, especially now, during the COVID-19 pandemic.

\section{References}

Adang, E.M.M., Gerritsma, A., Nouwens, E., van Lieshout, J. and Wensing, M. (2016), "Efficiency of the implementation of cardiovascular risk management in primary care practices: an observational study", Implementation Science, Implementation Science, Vol. 11 No. 1, pp. 1-7.

Akinci, F. and Patel, P. (2014), "Quality improvement in healthcare delivery utilizing the patientcentered medical home model”, Hospital Topics, Vol. 91 No. 4, pp. 96-104.

Akram, G., Tayyebeh, R., Farahnaz, A., Zahra, S. and Iman, D. (2017), "Quality improvement in healthcare delivery utilizing the patient-centered medical home model", Health Promotion Perspective, Vol. 7 No. 3, pp. 168-174.

Aumann, N., Baumeister, S., Rettig, R., Lieb, W., Werner, A., Döring, A., Peters, A., Koenig, W., Hannemann, A., Wallaschofski, H., Nauck, M., Stracke, S., Völzke, H. and Meisinger, Ch. (2015), "Regional variation of chronic kidney disease in Germany: results from two population-based surveys", Kidney and Blood Pressure Research, Vol. 40, pp. 231-243.

Avkiran, N.K. and Rowlands, T. (2003), "How better identify the true managerial performance: state of art using DEA", Omega International Journal of Management Science, Vol. 36, pp. 317-324.

Backfield, J., Olafsdottir, S. and Sosnaud, B. (2013), "Healthcare systems in comparative perspective: classification, convergence, institutions, inequalities, and five missed turns", Annual Review of Sociology, Vol. 39, pp. 127-146. 
Banker, R.D., Charnes, A. and Cooper, W. (1984), "Some models for estimating technical and scale inefficiencies in data envelopment analysis", Management Science, Vol. 30, pp. 1078-1092.

Baray, J. and Cliquet, G. (2013), "Optimizing locations through a maximum covering/p-median hierarchical model: maternity hospitals in France", Journal of Business Research, Vol. 66, pp. 127-132.

Bastian, N.D., Kang, H., Swenson, E.R., Fulton, L.V. and Griffin, P.M. (2016), "Evaluating the impact of hospital efficiency on wellness in the military health system", Military Medicine, Vol. 181 No. 8, pp. 827-834.

Bem, A., Predkiewicz, P., Ucieklak-Jez, P. and Siedlecki, R. (2015), "Profitability versus debt in hospital industry", European Financial Systems 2015: Proceedings of the 12th International Scientific Conference.

Biørn, E., Hagen, T., Iversen, T. and Magnussen, J. (2003), "The effect of activity-based financing on hospital efficiency: a panel data analysis of DEA efficiency scores 1992-2000", Health Care Management Science, Vol. 6 No. 4, pp. 271-83.

Birman, S.V., Pirondi, E. and Rodin, E.Y. (2003), "Application of DEA to medical clinics", Mathematical and Computer Modelling, Vol. 37, pp. 923-936.

Blatnik, P., Bojnec, Š. and Tušak, M. (2017), "Measuring efficiency of secondary healthcare providers in Slovenia", Open Medicine, Vol. 12 No. 1, pp. 214-225.

Boe, O. and Kvalvik, Ø. (2015), "Effective use of resources in the public management sector in Norway", Procedia Economics and Finance, Vol. 26 No. 2212, pp. 869-874.

Byrnes, P. and Valdmanis, V. (1994), “Analyzing technical and allocative efficiency of hospitals”, Data Envelopment Analysis: Theory, Methodology, and Applications, Springer, Dordrecht.

Caballer-Tarazona, M. and Vivas-Consuelo, D. (2016), "A cost and performance comparison of public private partnership and public hospitals in Spain”, Health Economics Review, Vol. 6 No. 1, doi: 10.1186/s13561-016-0098-2.

Charnes, A., Cooper, W. and Rhodes, E. (1978), "Measuring the efficiency of decision making units", European Journal of Operational Research, Vol. 2 No. 6, pp. 429-444.

Charnes, A., Cooper, W., Lewin, A.Y. and Seiford, L. (1994), Data Envelopment Analysis - Theory, Methodology and Applications, Kluwer Academic Publishers, London.

Cheng, G. (2014), Data Envelopment Analysis: Methods and MaxDEA Software, Intellectual Property Publishing House, Beijing.

Cheng, Z., Cai, M., Tao, H., He, Z., Lin, X., Lin, H. and Zuo, Y. (2016), "Efficiency and productivity measurement of rural township hospitals in China: a bootstrapping data envelopment analysis", BMJ Open, Vol. 6 No. 11, p. e011911.

Cooper, W.W., Seiford, L.M. and Tone, K. (2007), Data Envelopment Analysis: A Comprehensive Text with Models, Applications, References and DEA-Solver Software, Springer.

Cordero Ferrera, J.M., Cebada, E.C. and Murillo Zamorano, L.R. (2014), "The effect of quality and sociodemographic variables on efficiency measures in primary health care", The European Journal of Health Economics, Vol. 15 No. 3, pp. 289-302.

Cullinane, K., Wang, T.F., Song, D.W. and Ji, P. (2006), "The technical efficiency of container ports: comparing data envelopment analysis and stochastic Frontier analysis", Transportation Research Part A: Policy and Practice, Vol. 40 No. 4, pp. 354-374.

Cygańska, M. (2015), "Wykorzystanie analizy finansowej do oceny rentowności szpitali - Wybrane problemy", Prace Naukowe Uniwersytetu Ekonomicznego We Wrocławiu - Teoria Rachunkowości, Sprawozdawczość i Analiza Finansowa, Vol. 388, pp. 363-372.

Cygańska, M. (2019), "A clinical index for the measurement of hospital performance: development and validation”, Research Papers of Wrocław University of Economics, Vol. 63 No. 2, pp. 155-164.

Czypionka, T., Kraus, M., Mayer, S. and Röhrling, G. (2014), "Efficiency, ownership, and financing of hospitals: the case of Austria”, Health Care Management Science, Vol. 17 No. 4, pp. 331-347.
The efficiency of the healthcare sector in Poland 
IJPPM

71,7

Daniels, N. (2016), "Resource allocation and priority setting", in Barrett, H., Ortmann, L. and Dawson, A. (Eds), Public Health Ethics: Cases Spanning the Globe.

Dlouhý, M. (2016), "International comparison of health system performance in Visegrad countries", Casopis Lékaru Ceských, Vol. 155 No. 5, pp. 242-246.

Dubas-Jakóbczyk, K., Kocot, E., Czerw, A., Juszczyk, G., Karwowska, P. and Menne, B. (2020), "Health as an investment in Poland in the context of the Roadmap to implement the 2030 Agenda for Sustainable Development and Health 2020", WHO Regional Office for Europe, Copenhagen.

Dubas-Jakóbczyk, K., Kocot, E. and Kozieł, A. (2020), "Financial performance of public hospitals: a cross-sectional study among polish providers", International Journal of Environmental Research and Public Health, Vol. 17, p. 7, doi: 10.3390/ijerph17072188.

English, M., Mwaniki, P., Julius, T., Chepkirui, M., Gathara, D., Ouma, P.O., Cherutich, P., Okiro, E.A. and Snow, R.W. (2018), "Hospital mortality - a neglected but rich source of information supporting the transition to higher quality health systems in low and middle income countries", BMC Medicine, Vol. 16, p. 32.

Fanelli, S. and Zangrandi, A. (2017), "Assessment for improving the performance of NICUs: the Italian experience”, Health Services Management Research, Vol. 30 No. 3, pp. 168-178.

Fanelli, S., Bellù, R., Zangrandi, A., Gagliardi, L. and Zanini, R. (2020), "Managerial features and outcome in neonatal intensive care units: results from a cluster analysis", BMC Health Services Research, Vol. 20 No. 1, p. 957.

Ferrier, G. and Trivitt, J. (2013), "Incorporating quality into the measurement of hospital efficiency: a double DEA approach", Journal of Productivity Analysis, Vol. 40 No. 3, pp. 337-355.

Flokou, A., Aletras, V. and Niakas, D. (2017), "A window-DEA based efficiency evaluation of the public hospital sector in Greece during the 5-year economic crisis", PloS One, Vol. 12 No. 5, pp. 1-26.

Gannon, B. (2011), "Testing for variation in technical efficiency of hospitals in Ireland", American Journal of Preventive Medicine, Vol. 41 No. 4, pp. 149-151.

Ghafari, N., Pishvaee, M., Sadjadi, S. and R., S. (2019), "Performance assessment of medical diagnostic laboratories: a network DEA approach", Journal of Evaluation in Clinical Practice, Vol. 26 No. 5 , pp. 1504-1511, doi: 10.1111/jep.13337.

Ghahremanloo, M., Hasani, A., Amiri, M., Hashemi-Tabatabaei, M., Keshavarz-Ghorabaee, M. and Ustinovičius, L. (2020), "A novel DEA model for hospital performance evaluation based on the measurement of efficiency, effectiveness, and productivity", Engineering Management in Production and Services, Vol. 12 No. 1, pp. 7-19.

GUS (2019), Zdrowie I Ochrona Zdrowia W 2018 R, Central Statistical Office, Warszawa.

Hemmasi, A., Talaeipour, M., Khademi- Eslam, H., Farzipoor, S.R. and Pourmousa, S.H. (2011), "Using DEA window analysis for performance evaluation of Iranian wood panels industry", African Journal of Agricultural Research, Vol. 6 No. 7, pp. 1802-1806.

Hollingsworth, B. and Peacock, S.J. (2008), Efficiency Measurement in Health and Health Care, Routledge, London and New York.

Jacobs, R., Smith, P.C. and Street, A. (2013), Mierzenie Efektywności W Ochronie Zdrowia, Wolters Kluwer, Warszawa.

Jaworzyńska, M. (2016), "A comparative analysis of the health system financing in Poland and selected countries", Economics and Sociology, Vol. 9 No. 3, pp. 41-51.

Jehu-Appiah, C., Sekidde, S., Adjuik, M., Akazili, J., Almeida, S.D., Nyonator, F., Baltussen, R., Asbu, E.Z. and Kirigia, J.M. (2014), "Ownership and technical efficiency of hospitals: evidence from Ghana using data envelopment analysis", Cost Effectiveness and Resource Allocation, Vol. 12 No. 1, pp. 1-13.

Jena, A.B. and Philipson, T.J. (2013), "Endogenous cost-effectiveness analysis and health care technology adoption", Journal of Health Eonomics, Vol. 32, pp. 172-180. 
Jewczak, M. and Żółtaczek, A. (2011), "Ocena efektywności technicznej podmiotów sektora opieki zdrowotnej w Polsce w latach 1999 - 2009 w ujęciu przestrzenno-czasowym na przykładzie szpitali ogólnych”, Problemy Zarzadzania, Vol. 9 No. 3, pp. 194-210.

Jewczak, M. and Żóttaszek, A. (2011), "Spatial shift-share analysis as a health policy tool", Acta Universitatis Lodziensis. Folia Oeconomica, Vol. 252, pp. 87-100.

Jia, T. and Yuan, H. (2017), "The application of DEA (Data Envelopment Analysis) window analysis in the assessment of influence on operational efficiencies after the establishment of branched hospitals”, BMC Health Services Research, Vol. 17 No. 1, pp. 1-8.

Journard, I., Andre, C. and Nicq, C. (2010), Health Care Systems: Efficiency and Institutions, OECD Economics Department Working Papers, No. 769, OECD Publishing, Paris, doi: 10.1787/ 5kmfp51f5f9t-en.

Kapoor, P. (2011), "Why quality in healthcare”, Medical Journal Armed Forces India, Vol. 67 No. 3, pp. 206-208.

Kazley, A. and Ozcan, Y. (2009), "Electronic medical record use and efficiency: a DEA and windows analysis of hospitals", Socio-Economic Planning Sciences, Vol. 43 No. 3, pp. 209-216.

Kenny, K. (2015), "Healthcare and compassion: towards an awareness of intersubjective vulnerability: comment on "why and how is compassion necessary to provide good quality healthcare?", International Journal of Health Policy and Management, Vol. 4 No. 9, pp. 627-629.

Khushalani, J. and Ozcan, Y.A. (2017), "Are hospitals producing quality care efficiently? An analysis using Dynamic Network Data Envelopment Analysis (DEA)", Socio-Economic Planning Sciences, Elsevier, Vol. 60, pp. 15-23.

Kinkorová, J. and Topolčan, O. (2012), "Overview of healthcare system in the Czech Republic", The EPMA Journal, Vol. 3 No. 1, p. 4, doi: 10.1007/s13167-012-0139-9.

Knapp, M., Pan, Y. and McCrone, P. (2012), "Cost-effectiveness comparison between antidepressant treatments in depression: evidence from database analyses and prospective studies", Journal of Affective Disorders, Vol. 139, pp. 113-125.

Kozierkiewicz, A., Natkanie, M., Megas, B., Gilewski, D., Ignatowicz, M. and Waśko, B. (2019), Indeks Sprawności Ochrony Zdrowia 2018, Warszawa.

Kruk, M.E., Gage, A.D., Joseph, N.T., Danaei, G. and García-SaisóSalomon, S.J.A. (2018), "Mortality due to low-quality health systems in the universal health coverage era: a systematic analysis of amenable deaths in 137 countries", Lancet, Vol. 392 No. 10160, pp. 2203-2212.

Kujawska, J. (2018), "Efficiency of healthcare systems in European countries - the DEA network approach", Metody Ilościowe w Badaniach Ekonomicznych, Vol. 19 No. 1, pp. 60-70.

Kuszewski, K., Krysińska, M. and Różycka, A. (2014), "Planowanie sieci szpitali. Historia pewnej inicjatywy", Zdrowie Publiczne i Zarzadzanie, Vol. 12 No. 2, pp. 129-133.

Lachowska, A. (2017), "Efficiency of public and nonpublic primary health care providers in Poland", Engineering Management in Production and Services, Vol. 9 No. 2, pp. 57-63.

Lamovšek, N. and Klun, M. (2020), "Efficiency of medical laboratories after quality standard introduction: trend analysis of selected EU countries and case study from Slovenia”, Central European Public Administration Review, Vol. 18 No. 1, pp. 143-163.

Ley, E. (1991), "Efficiencia productiva: un estudio aplicado al sector hospitalario", Investicaionnes Economicas, Vol. 15 No. 1, pp. 71-88.

Liu, L., Oza, S., Hogan, D., Chu, Y., Perin, J., Zhu, J., Lawn, J.E., Cousens, S., Mathers, C. and Black, R.E. (2016), "Global, regional, and national causes of under-5 mortality in 2000-15: an updated systematic analysis with implications for the sustainable development goals", The Lancet, The Author(s). Published by Elsevier, This is an Open Access article under the CC BY License, Vol. 388 No. 10063, pp. 3027-3035.

Lobo, M.S.D.C. and Araujo, E.C. (2017), "Efficiency analysis of public health spending in Brazilian capitals using network data envelopment analysis (DEA)", The Central European Review of Economics and Management, Vol. 1 No. 4, p. 147. 
IJPPM

71,7

Madureira, L., Santos, J., Ferreira, A. and Guimarães, H. (2013), "Feasibility study on the valuation of public goods and externalities in EU agriculture”, JRC Working Papers JRC83468, Joint Research Centre. doi: 10.2791/22366.

Magda, I. and Szczygielski, K. (2011), Assessment of the Possibilities of Improving the Operation of the Polish Healthcare System, Co-Payment and Private Health Insurance, Warsaw.

Magnussen, J. and Nyland, K. (2008), "Measuring efficiency in clinical departments", Health Policy, Vol. 87 No. 1, pp. 1-7.

McKillop, D., Glass, C., Kerr, C. and McCallion, G. (1999), "Efficiency in Northern Ireland hospitals: a non-parametric analysis", Economic and Social Review, Vol. 30, pp. 175-196.

Meisinger, C., Heier, M., Völzke, H., Löwel, H., Mitusch, R., Hense, H. and Lüdemann, J. (2006), "Regional disparities of hypertension prevalence and management within Germany", Journal of Hypertension, Vol. 24 No. 2, pp. 293-299.

Miclos, P.V., Calvo, M.C.M. and Colussi, C.F. (2017), "Evaluation of the performance of actions and outcomes in primary health care", Revista de Saúde Pública, Vol. 51, p. 86.

Mihalyi, P. (2014), "Post-socialist health systems in transition: Czech Republic, Hungary and Poland", Central European University Working Paper, Vol. 4 No. 1.

Ministry of Health (2020), "Quality monitoring center", Hospital Accreditation, available at: https:// www.cmj.org.pl/akredytacja/cotojest.php (accessed 20 October 2020).

Miszczyńska, K. (2018a), "Determinants of public healthcare units indebtedness-the case of public hospitals in Lodz", Proceedings of the European Financial Systems Conference 2018, Masaryk University, Brno, pp. 420-426.

Miszczyńska, K. (2018b), "Podejście nieparametryczne w ocenie efektywności sektora ochrony zdrowia w Polsce”, Metody Ilościowe w Badaniach Ekonomicznych, Vol. 19 No. 3, pp. 228-237.

Miszczyńska, K. (2019), Efektywność Funkcjonowania Szpitali Publicznych W Łodzi, Uniwersytet Łódzki, Łódź.

Miszczyńska, K. (2020), "Do polish hospitals perform well? Selected aspects of financial performance", Finance and Sustainability: Proceedings from the 2nd Finance and Sustainability Conference, Wroclaw, Spirnger, p. 364.

Miszczyńska, K. and Antczak, E. (2020), Uwarunkowania Zadłuzenia Szpitali W Polsce, University of Lodz, Lodz.

Miszczyńska, K.M. and Miszczyński, P.M. (2020), "Inpatient costs in the perspective of Polish health policy: scenario analysis", South East European Journal of Economics and Business, Vol. 15 No. 2, pp. 43-56.

Mitropoulos, P., Mitropoulos, I. and Giannikos, I. (2013), "Combining DEA with location analysis for the effective consolidation of services in the health sector", Computers and Operations Research, Elsevier, Vol. 40 No. 9, pp. 2241-2250.

Oikonomou, N., Tountas, Y., Mariolis, A., Souliotis, K., Athanasakis, K. and Kyriopoulos, J. (2016), "Measuring the efficiency of the Greek rural primary health care using a restricted DEA model; the case of southern and western Greece", Health Care Management Science, Vol. 19 No. 4, pp. 313-325.

Onen, Z. and Sayin, S. (2018), "Evaluating healthcare system efficiency of OECD countries: a DEA based study", in Kahraman, C. and Topcu, Y.I. (Eds), Operations Research Applications in Health Care Management, Springer.

O’Neill, L., Rauner, M., Heidenberger, K. and Kraus, M. (2008), “A cross-national comparison and taxonomy of DEA-based hospital efficiency studies”, Socio-Economic Planning Sciences, Vol. 42 No. 3, pp. 158-189.

Pelone, F., Kringos, D., Valerio, L., Romaniello, A., Lazzari, A., Ricciardi, W. and Giulio de Belvis, A. (2012), "The measurement of relative efficiency of general practice and the implications for policy makers", Health Policy, Vol. 107 Nos 2-3, pp. 258-68. 
Pulina, M., Detotto, C. and Paba, A. (2010), "An investigation into the relationship between size and efficiency of the scale efficiencies of the Italian hospitality sector: a window DEA approach", European Journal of Operational Research, Vol. 204, pp. 613-620.

Rój, J. (2011), "Ocena efektywności systemów ochrony zdrowia w wybranych krajach Unii Europejskiej z wykorzystaniem podejścia nieparametrycznego”, Acta Universitatis Lodziensis, Vol. 1, pp. 143-153, Folia Oeconomica, Vol. Acta Unive.

Sajid, M.S. and Baig, M.K. (2007), "Quality of health care: an absolute necessity for public satisfaction", International Journal of Health Care Quality Assurance, Vol. 20 No. 6, pp. 545-548.

The efficiency of the healthcare sector in Poland

Samut, K. and Cafrı, R. (2016), "Analysis of the efficiency determinants of health systems in OECD countries by DEA and panel Tobit", Social Indicators Research, Vol. 129 No. 1, pp. 113-132.

Sathye, M. (2003), "Efficiency of banks in a developing economy: the case of India", European Journal of Operational Research, Vol. 48 No. 3, pp. 662-671.

Serván-Mori, E., Chivardi, C., Mendoza, M. and Nigenda, G. (2018), "A longitudinal assessment of technical efficiency in the outpatient production of maternal health services in México", Health Policy Plan, Vol. 33 No. 8, pp. 888-897.

Stefko, R., Gavurova, B. and Kocisova, K. (2018), "Healthcare efficiency assessment using DEA analysis in the Slovak Republic", Health Economics Review, Health Economics Review, Vol. 8 No. 1, doi: 10.1186/s13561-018-0191-9.

Sufian, F. (2007), "Trends in the efficiency of Singapore's commercial banking groups: a nonstochastic Frontier DEA window analysis approach", International Journal of Productivity and Performance Management, Vol. 56 No. 2, pp. 99-136.

Suppreme Chamber of Control (2019), System Ochrony Zdrowia W Polsce - Stan Obecny I Pożadane Kierunki Zmian, NIK, Warszawa.

Szetela, P. (2015), "Rola samorządu terytorialnego w polskim systemie ochrony zdrowia: organizator, podmiot tworzacy oraz płatnik", Zdrowie Publiczne i Zarzadzanie, Vol. 13 No. 1, pp. 55-68.

Szetela, P. (2017), "Coordination and integration in health care. The concepts for the next reform - Part I", Zdrowie Publiczne i Zarzadzanie, Vol. 15 No. 3, pp. 207-218.

Tambeur, W., Stijnen, P., Vanden, B.G., Maertens, P., Weltens, C., Rademakers, F. and Bruyneel, L. (2019), "Standardised mortality ratios as a user-friendly performance metric and trigger for quality improvement in a Flemish hospital network: multicentre retrospective study", $B M J$ Open, Vol. 9 No. 9, e029857, doi: 10.1136/bmjopen-2019-029857.

Tarantola, D., Parmet, W.E., Costanza, M.C. and Yu, S. (2020), "COVID-19 exposes need for progressive criminal justice reform", American Journal of Public Health, Vol. 110 No. 7, pp. 967-968.

Tubek, S. (2010), "Rola samorządu terytorialnego w funkcjonowaniu systemu ochrony zdrowia", Rynek Zdrowia, Vol. 10, available at: https://www.rynekzdrowia.pl/ (accessed 15 August 2020).

Vanberkel, P.T., Boucherie, R.J. and Hans, E.W. (2012), "Efficiency evaluation for pooling resources in health care", OR Spectrum, Vol. 34, pp. 371-390.

Varabyova, Y. and Schreyögg, J. (2013), "International comparisons of the technical efficiency of the hospital sector: panel data analysis of OECD countries using parametric and non-parametric approaches", Health Policy, Vol. 112 Nos 1-2, pp. 70-79.

Votápková, J. and Štastná, L. (2013), "Efficiency of hospitals in the Czech Republic", Prague Economic Papers, Vol. 22 No. 4, pp. 524-541.

Wang, C.N., Lin, H.S., Hsu, H.P., Le, V.T. and Lin, T.F. (2016), "Applying data envelopment analysis and grey model for the productivity evaluation of Vietnamese agroforestry industry", Sustainability, Vol. 8 No. 11. doi: 10.3390/su8111139.

Webb, R. (2003), "Levels of efficiency in UK retails banks: a DEA window analysis", International Journal of the Economics of Business, Vol. 10 No. 3, pp. 305-322. 
IJPPM

71,7

Wendt, C. (2009), "Mapping European healthcare systems: a comparative analysis of financing, service provision and access to healthcare”, Journal of European Social Policy, Vol. 19 No. 5, pp. $432-445$.

Willan, A.R. and Kowgier, M.E. (2008), "Cost-effectiveness analysis of a multinational RCT with a binary measure of effectiveness and an interacting covariate", Journal of Health Economics, Vol. 17, pp. 777-791.

Worthington, A.C. (2004), "Frontier efficiency measurement in health care: a review of empirical techniques and selected applications", Medical Care Research and Review, Vol. 61 No. 2, pp. 135-70.

Zakowska, I. and Godycki-Cwirko, M. (2020), "Data envelopment analysis applications in primary health care: a systematic review", Family Practice, Vol. 37 No. 2, pp. 147-153.

\section{About the authors}

Katarzyna Miszczynska. Doctor of economic sciences. An assistant professor in the Department of Public Finance at the University of Lodz, Poland. Doctoral thesis defended in the Faculty of Economics and Sociology in the University of Lodz. Graduate of the University of Lodz. Received a master's degree in Information Technology and Econometrics in 2010 and in 2011 her second master's degree in Finance and Accounting. Since 2010 working at the University of Lodz. Expert in health economics with a particular emphasis on public finance and econometric modeling. Author of several academic articles, monograph sections, analytical works. Since 2017 leader of scientific grant Multicriteria assessment of efficiency of public hospitals in Poland and identification of determinants of their indebtedness financed by the National Science Centre in Poland. Katarzyna Miszczynska is the corresponding author and can be contacted at: katarzyna.miszczynska@uni.lodz.pl

Piotr Marek Miszczyński. Doctor of economic sciences. An assistant professor in the Department of Operations Research at the University of Lodz, Poland. Doctoral thesis defended in the Faculty of Economics and Sociology in the University of Lodz. Graduate of the University of Lodz. Received a master's degree in Information Technology and Econometrics in 2009 and in 2012 his second master's degree in Finance and Accounting. Since 2010 working at the University of Lodz. Expert in banking with a particular emphasis on quantitive methods, simulation and optimization modeling. Author of several academic articles and analytical works. Since 2015 took part in several banking projects as an expert in the field of strategic analysis, business planning and financial modelling.

For instructions on how to order reprints of this article, please visit our website:

www.emeraldgrouppublishing.com/licensing/reprints.htm

Or contact us for further details: permissions@emeraldinsight.com 